\section{Estuaries and Coasts}

July 2009, Volume 32, Number 4, Pages 678-693

http://dx.doi.org/10.1007/s12237-009-9160-1

(c) 2009 Springer. Part of Springer Science+Business

Media

The original publication is available at http://www.springerlink.com
Archimer, archive institutionnelle de l'Ifremer http://www.ifremer.fr/docelec/

\title{
Flocculation Potential of Estuarine Particles: The Importance of Environmental Factors and of the Spatial and Seasonal Variability of Suspended Particulate Matter
}

Romaric Verney ${ }^{1,}{ }^{*}$, Robert Lafite ${ }^{2}$ and Jean-Claude Brun-Cottan ${ }^{3}$

\author{
${ }^{1}$ IFREMER, DYNECO-PHYSED, BP70, 29280 Plouzane Cedex, France \\ 2 UMR CNRS 6143 M2C, University of Rouen, 76821 Mont Saint Aignan Cedex, France \\ ${ }^{3}$ UMR CNRS 6143 M2C, University of Caen, 24 Allée des Tilleuls, 14000 Caen, France \\ *: Corresponding author : R. Verney, email address : Romaric.Verney@ifremer.fr
}

\begin{abstract}
:
Estuarine systems are complex environments where seasonal and spatial variations occur in concentrations of suspended particulate matter, in primary constituents, and in organic matter content. This study investigated in the laboratory the flocculation potential of estuarine-suspended particulate matter throughout the year in order to better identify the controlling factors and their hierarchy. Kinetic experiments were performed in the lab with a "video in lab" device, based on a jar test technique, using suspended sediments sampled every 2 months over a 14-month period at three stations in the Seine estuary (France). These sampling stations are representative of (1) the upper estuary, dominated by freshwater, and (2) the middle estuary, characterized by a strong salinity gradient and the presence of an estuarine turbidity maximum. Experiments were performed at a constant low turbulent shear stress characteristic of slack water periods (i.e., a Kolmogorov microscale $>1,000 \mu \mathrm{m}$ ). Flocculation processes were estimated using three parameters: flocculation efficiency, flocculation speed, and flocculation time. Results showed that the flocculation that occurred at the three stations was mainly influenced by the concentration of the suspended particulate matter: maximum floc size was observed for concentrations above $0.1 \mathrm{~g} \mathrm{I}^{-1}$ while no flocculation was observed for concentrations below $0.004 \mathrm{~g} \mathrm{I}^{-1}$. Diatom blooms strongly enhanced flocculation speed and, to a lesser extent, flocculation efficiency. During this period, the maximum flocculation speed of $6 \mu \mathrm{m} \mathrm{min}{ }^{-1}$ corresponded to a flocculation time of less than 20 min. Salinity did not appear to automatically enhance flocculation, which depended on the constituents of suspended sediments and on the content and concentration of organic matter. Examination of the variability of $2 \mathrm{D}$ fractal dimension during flocculation experiments revealed restructuring of flocs during aggregation. This was observed as a rapid decrease in the floc fractal dimension from 2 to 1.4 during the first minutes of the flocculation stage, followed by a slight increase up to 1.8. Deflocculation experiments enabled determination of the influence of turbulent structures on flocculation processes and confirmed that turbulent intensity is one of the main determining factors of maximum floc size.
\end{abstract}

Keywords: Flocculation - Cohesive sediment - Floc structure - Diatom bloom - Kolmogorov microscale - Seine estuary (France) 


\section{Introduction}

Sediment transport processes in estuarine environments control the fate of suspended particulate matter (SPM), and of all contaminants associated with the particulate phase, including bacteria and viruses, as well as chemical and metallic contaminants. The transport of particles in estuaries is governed by tidal currents, river flow, waves, bathymetry, the salinity gradient and SPM characteristics. Transport is driven by a well-known cycle: suspension, flocculation, settling, deposition, erosion, resuspension (Eisma, 1993).

Flocculation processes are key factors to be investigated, as they control the size, structure and density of suspended particles (Gibbs, 1985; van Leussen, 1994), followed by their ability to settle or to be maintained in suspension. SPM are made up of particles of various natures: clay minerals, carbonates, fine sand, diatoms, bacteria, organic fragments, and organic biofilms (Eisma, 1993). In estuaries, these primary particles are usually organized in microflocs and macroflocs. Microflocs are dense, quasi-spherical, resistant to turbulent mixing, and are small: different maximum sizes have been proposed: $100 \mu \mathrm{m}$ (Lafite, 2001), $125 \mu \mathrm{m}$ (Eisma, 1993) or $160 \mu \mathrm{m}$ (Manning and Dyer, 1999). Under favourable conditions, microflocs collide with each other, flocculate and then form larger aggregates, referred to as macroflocs. Macroflocs are characterized by lower densities and larger sizes of up to several millimetres (Eisma et al., 1983; Manning et al., 2004). They present low cohesive strength, and can be fragmented by shear forces (Kranenburg, 1999; Jarvis et al., 2005).

Previous studies focused both on the influence of the concentration of SPM, and the intensity of turbulence on particles (Dyer, 1986; van Leussen, 1994; Mikes et al., 2004; Uncles et al., 2006, Winterwerp, 2006), and on the influence of the salinity gradient on clay particles 
(Migniot, 1968; Thill et al., 2001). However, studies of the influence of SPM constituents on the dynamics of macroflocs are scarce (Eisma et al., 1983; Eisma, 1993; van Leussen, 1994; van der Lee, 2000; Mikes et al., 2004). These authors concluded that organic matter and diatom blooms may enhance flocculation processes, without quantifying their effect. Sanford et al (2001) also reported a seasonal change in particle settling velocity in Chesapeake Bay, implying a change in floc characteristics. A mesocosm study was performed to examine the effect of a simulated diatom bloom on the formation of macroflocs (Alldredge et al., 1995; Passow and Alldredge, 1995). The results obtained from these studies demonstrated that during the bloom period, the concentration of the particulate organic carbon increased, thus enhancing flocculation processes, as observed by an increase in the number of macroflocs of more than $500 \mu \mathrm{m}$. Recently, Lunau et al. (2006) successfully examined the influence of diatom blooms and bacteria on floc growth. Organic matter content was also shown to affect the structure of the flocs, as they tend to increase the aggregation rate and thus to the formation of low density macroflocs (Chen and Eisma, 1995).

The present study examined the influence of the spatial and temporal variability of natural SPM characteristics on their flocculation potential using a laboratory flocculator (Jar-Test device). Therefore, this study focused exclusively on flocculation activity during the most favourable hydrodynamic conditions, i.e. periods of low turbulence, which correspond to slack water periods in the estuary. The dynamical behaviour of floc populations during a tidal cycle is beyond the scope of this experimental work.

Flocculation processes are characterized by kinetic reactions and steady-state macrofloc sizes. The main objectives of the study were to i) provide new information about interactions between the main parameters that control flocculation processes (turbulence, salinity, SPM 
Verney, Lafite, Brun-Cottan -- 6

concentration, organic matter content and diatom blooms) and ii) evaluate their impact and relative contribution to potential flocculation activity over a period of one year. 


\section{Study area}

The Seine estuary is a meandering macrotidal system flowing into the English Channel through a shallow bay, and is limited $160 \mathrm{~km}$ upstream from the estuary mouth by Poses lock (Fig. 1). Hydrodynamic conditions and sediment supply in the estuary are controlled at varying timescales by the fluvial discharge, the tidal range and local winds at the estuary mouth. In 2004-2005, the annually-averaged fluvial discharge was $370 \mathrm{~m}^{3} \mathrm{~s}^{-1}$ with marked seasonal variations: high river flows (i.e. above $700 \mathrm{~m}^{3} \mathrm{~s}^{-1}$ ) in winter, and low river flows (around $200 \mathrm{~m}^{3} \mathrm{~s}^{-1}$ ) in summer. The tidal range at the estuary mouth varies from $8 \mathrm{~m}$ during spring tides to $3 \mathrm{~m}$ during neap tides. When propagating into the estuary, the tidal wave shape becomes more asymmetric (i.e. short floods and long ebbs). At the upstream limit of the estuary, the tidal range is less than $1 \mathrm{~m}$. According to the Fairbridge classification, the Seine estuary is divided into three compartments: a fresh water fluvial compartment, a brackish water compartment characterised by salinity gradients, and a marine compartment (Fig. 1) (Guezennec, 1999).

In 2004-2005, the total solid flux entering the estuary was estimated to be $650,000 \mathrm{t}$, and came from miscellaneous natural and anthropogenic sources. The Seine River provides 500,000 t of sediments each year, mostly during high water discharge (80\% of the annual fluvial solid fluxes at Poses, Avoine, 1986). This material corresponds to the drainage of the Seine catchments area $\left(67,000 \mathrm{~km}^{2}\right.$ upstream from Poses), where $40 \%$ of French industry is concentrated. The other sources are its catchments area (81,000 t), primary production (60,000 t) and domestic and industrial wastes (11,000 t) (Avoine, 1981; Avoine, 1986; Guezennec, 1999). The marine source of sediment to the Seine estuary is small (Dupont, 
2001) and is thus not accounted for in this study. Daily average SPM concentration values at Poses are less than $0.01 \mathrm{~g} \mathrm{l}^{-1}$ during low water discharge periods; they increase up to $0.2 \mathrm{~g} \mathrm{l}^{-1}$ during high river flow. Incoming SPM is mainly composed of silty clay (kaolonite and smectite (25-40\%), carbonates (20-30\%) and organic matter (10-15\%) (Lesourd, 2000). Yearly primary production is linked to the diatom blooms (Lafite, 1990) that occur in spring and autumn. These blooms show peaks of chlorophyll a with a concentration of up to $100 \mu \mathrm{g}$ $\mathrm{l}^{-1}$ and particulate organic carbon at concentrations of up to $3 \mathrm{mg} \mathrm{l}^{-1}$.

SPM are transported seaward or can be deposited on intertidal mudflats (seasonally) or in the navigation channel and harbour structures, requiring dredging operations. SPM are trapped in an Estuarine Turbidity Maximum (ETM) due to the tidal dynamics (Avoine, 1981; Le Hir et al, 2001). The turbidity maximum total mass has been estimated at between 300,000 $\mathrm{t}$ and 500,000 t (Le Hir et al., 2001), with maximum concentrations at the surface of the water ranging from 1 to $2 \mathrm{~g} \mathrm{l}^{-1}$ (Avoine, 1981). The furthest upstream extent of the turbidity maximum is located near Caudebec en Caux (kp300) corresponding to low river flow during spring tide conditions. During periods of high freshwater discharge $\left(>1000 \mathrm{~m}^{3} \mathrm{~s}^{-1}\right)$ the turbidity maximum zone is flushed out of the estuary mouth into the Seine Bay.

Flocculation and deflocculation processes were studied in the laboratory with a Jar-test flocculator using Seine estuary SPM. Samples were collected at three stations located along the Seine estuary every two months for a period of 14 months starting in February 2004. The upstream station (station $1-\mathrm{S} 1$ ) is located in the fluvial freshwater part of the estuary (Rouen, kp 245). The downstream station (station 3 - S3) is located in the ETM, at Tancarville Bridge (kp 335). An intermediate station (station 2 - S2) was chosen at Caudebec en Caux (kp 310), seasonally influenced either by the freshwater part or the ETM. The following naming convention was considered to identify the samples at the three sites along the study period: 
Sx_MMYY for a sample collected at station $\mathrm{x}$ at the corresponding year (YY) and month (MM) As sediment dynamics (advection of the ETM, deposition) are strong at the tidal scale, a sampling strategy was adopted to enable collection of SPM under similar hydrodynamic conditions throughout the year. This strategy meant that all samples were collected at the surface of the water, one hour before local high water, when tidal amplitude at the estuary mouth ranged between $5 \mathrm{~m}$ and $6 \mathrm{~m}$. The time interval between sampling and experiments was reduced to between 2 and 4 hours to avoid possible SPM changes due to biological or microbial degradation. 


\section{Material and methods}

\section{VIL: Jar-test flocculator}

Flocculation experiments were performed in the Jar-test flocculator “Video In Lab” (VIL) (Mikes et al., 2004; Verney, 2006) at ambient temperature. This device is a $13 \mathrm{~cm}$ wide $20 \mathrm{~cm}$ high cylindrical glass bowl equipped with a ten-speed impeller (from $\omega_{0}$ to $\omega_{10}$ ) to control turbulent agitation (Fig. 2). Hydrodynamic calibration was performed with a Laser Doppler Velocimeter (LDV) to estimate the turbulent kinetic energy and the main turbulent scales, e.g. the shear rate $G$ and the Kolmogorov microscale $\eta$ (Verney, 2006). The particular geometry of the jar-test device as well as the blade shape induces low spatial heterogeneity of $\eta$, especially at the lowest impeller speeds $\omega_{0}$ (Fig. 3). Previous studies have demonstrated that the flocculation results obtained with the VIL are consistent, confirming the validity of the device. When these values were compared with in-situ measurements (van Leussen, 1994; Verney et al., 2006), $\eta$ values generated within the flocculator were able to reproduce the whole natural turbulent spectrum, from the highest flood/ebb currents $\left(\omega_{10}: \eta<300 \mu \mathrm{m}\right)$ to the slack water period $\left(\omega_{0:} \eta>1000 \mu \mathrm{m}\right)$ (Fig. 3).

\section{Description of the population of particles}

Grain-size distribution of floc populations was obtained from floc image recordings and post processing. The VIL is equipped with a Sony CCD camera and lens that provide $8 \mu \mathrm{m}$ pixel resolution images for maximum enlargement. A backlight is positioned opposite the CCD camera to provide a uniform white background upon which flocs appear as greyscale 
silhouettes (see Fig. 2). Due to optical limitations, the VIL device is operational only for SPM concentrations below $0.35 \mathrm{~g} \mathrm{l}^{-1}$. Particle separation is automatically processed by the ELLIX® software (Microvision ${ }^{\circledR}$ ), which uses image thresholding to detect particles larger than 50 $\mu \mathrm{m}$. Separation results were individually checked to remove detection errors. This postprocessing provides Feret length $\left(\mathrm{L}_{\mathrm{f}}\right)$ and width $\left(\mathrm{l}_{\mathrm{f}}\right)$, length (a) and width (b) of the closest ellipse inscribing the floc, floc area (A) and perimeter (P) from the number of pixels that comprise the floc and boundary detection. Observing and comparing flocs requires the choice of the best characteristic size i.e. that represents the 3D particle as closely as possible. Different characteristic sizes have been used in many studies to represent particles: the square-box diameter $\left(\mathrm{D}_{\mathrm{SB}}\right)$, which corresponds to the smallest box inscribing the floc (Maggi, 2005), the Feret diameter $\left(D_{f}\right)(1)$, which is calculated from the Feret length $L_{f}$ and width $l_{f}$ (van Leussen, 1994; Manning and Dyer, 1999), the nominal elliptical diameter $\left(D_{e}\right)(2)$, which corresponds to the diameter of the sphere with a projected cross-section area equivalent to the ellipse area inscribing the floc (from the large (a) and small (b) ellipse axis) (Sternberg et al., 1999), and the surface equivalent diameter $\left(D_{a}\right)(3)$, calculated as the diameter of the sphere with a projected area A equal to the detected particle area (Billiones et al., 1999; Flory et al., 2004; Mikes et al., 2004).

$$
\begin{aligned}
& D_{f}=\sqrt{L_{f} * l_{f}} \\
& D_{e}=\sqrt{a * b} \\
& D_{a}=\sqrt{\frac{4 A}{\pi}}
\end{aligned}
$$

$D_{\mathrm{f}}$ and $\mathrm{D}_{\mathrm{SB}}$ depend on the orientation of the floc from the vertical and horizontal axis. This method can consequently only be used for particles that only settle in non-turbulent flows, and was thus not suitable for the present study. $\mathrm{D}_{\mathrm{e}}$ is a reliable floc size as it corresponds to the geometrical apparent lengths but does not integrate the roughness of natural particles. $\mathrm{D}_{\mathrm{a}}$ 
provides the closest approximation of the mass of an aggregate, and was consequently used as characteristic size in this study. In addition, this meant that our experimental results could be compared with numerical models (Verney, 2006). Finally, the average diameter of the 10 largest flocs $\left(D_{\max 10}\right)$ was calculated to estimate the maximum floc size.

In addition to the characteristic size, the circularity $\mathrm{C} \mathrm{(4)} \mathrm{and} \mathrm{the} \mathrm{2D} \mathrm{fractal} \mathrm{dimension} \mathrm{of} \mathrm{the}$ flocs $n_{f}(5)$ were computed. C represents the ratio between the floc area and square perimeter P of the detected floc.

$$
\mathrm{C}=\frac{4 \pi \mathrm{A}}{\mathrm{P}^{2}}
$$

The fractal dimension corresponds to the slope of the log/log representation of the floc area A and the floc length a for the total population of particles.

$$
\log (A)=n_{f} \log (a)
$$

where a is the ellipse length containing the floc.

C values range from epsilon to 1 , the value of 1 corresponding to a full sphere and $n_{\mathrm{f}}$ values range from 1 to 2 , with $\mathrm{n}_{\mathrm{f}}=2$ representing a sphere. For $\mathrm{n}_{\mathrm{f}}$ values below 2, it should be noted that the 2D fractal dimension corresponds to the 3D fractal dimension (Meakin, 1988), and that enables calculation of floc density (Kranenburg, 1994):

$$
\rho_{\mathrm{f}}=\rho_{\mathrm{w}}+\left(\rho_{\mathrm{s}}-\rho_{\mathrm{w}}\right)\left(\frac{\mathrm{D}_{\mathrm{p}}}{\mathrm{D}_{\mathrm{a}}}\right)^{3-\mathrm{n}_{\mathrm{f}}}
$$

where $\rho_{\mathrm{w}}$ and $\rho_{\mathrm{s}}$ is the clay/silt density. $\mathrm{D}_{\mathrm{p}}$ is the diameter of the primary particles that make up the floc, in this case $4 \mu \mathrm{m}$ clay particles.

Floc size distribution is computed using the surface diameter $D_{a}$ weighted with the floc detected area to better represent the ratio between small and large flocs. The characteristic size of a population of particles corresponds to the mean surface diameter $D_{a}$ weighted with the detected surface area of the floc: 


$$
\left\langle D_{a}\right\rangle=\frac{\sum_{i=1}^{N} D_{a}(i) \cdot A(i)}{\sum_{i=1}^{N} A(i)}
$$

Hereafter in this study, the average diameter $\left\langle D_{a}\right\rangle$ is denoted $D_{a}$.

\section{$\underline{\text { Kinetic experiments }}$}

According to most of the recent studies on the influence of turbulence on floc sizes (Milligan and Hill, 1998; Manning and Dyer, 1999), flocculation experiments are carried out with a low turbulent intensity. This allows an optimum flocculation state that corresponds to slack water periods (Uncles et al., 2006) $\left(\omega_{0}: \eta=1000 \mu \mathrm{m}\right)$. All our experiments were performed following a standardized procedure, which consists first in breaking all potential macroflocs in suspension by applying the largest shear stress $\omega_{10}(\eta=300 \mu \mathrm{m})$ for a period of $5 \mathrm{~min}$. Next stirring is dropped to $\omega_{0}$ to reach $\eta=1000 \mu m$, and the test starts. The flocculation test lasts 120 min, which corresponds to the flocculation timescale (van Leussen, 1994; Maggi, 2005) and is close to the average length of slack water periods in the Seine estuary: periods where $\eta>1000 \mu \mathrm{m}$ in the estuary ranges from 1 to 5 hours (Fig. 3). During the experiment, bursts of 60 images were recorded to calculate the floc size distribution, with increasing time steps between bursts, to accurately monitor flocculation processes in the first $30 \mathrm{~min}$. For each station, two series of experiments were performed at two salinitiy values (raw salinity and 20 PSU) to examine the influence of strong variations in salinity on the flocculation state. Populations of flocs were represented by the mean surface diameter $D_{a}$ at each time step. 
For all experiments, deflocculation tests were carried out after the flocculation period by increasing the turbulent intensity stepwise (5 min steps) from $\eta=1000 \mu \mathrm{m}$ to $\eta=300 \mu \mathrm{m}$, to investigate the breaking of particles as a function of SPM characteristics.

\section{Characterisation of the suspended particulate matter}

The parameters that were used to define SPM variability were the following: concentration of SPM dry mass, grain size of microflocs, chlorophyll a and phaeopigment contents, particulate organic carbon (POC) and C:N ratio. SPM concentration was obtained after sample filtration (filtrated volume ranging from 0.1 to $1 \mathrm{~L}$ depending on turbidity) and drying on pre-weighed $0.45 \mu \mathrm{m}$ pore diameter GFF filters. This strategy ensured a precision of $0.0001 \mathrm{~g} \mathrm{l}^{-1}$ for the lowest SPM concentrations. Microfloc grain-size distribution was measured in strongly agitated samples using a Coulter Counter LS230. Chlorophyll a was measured by spectrophotometry. Between $0.1 \mathrm{~L}$ and $1 \mathrm{~L}$ of collected sample were filtrated on $0.45 \mu \mathrm{m}$ pore diameter GFF filters. Pigments were extracted with $90 \%$ pure acetone for $24 \mathrm{~h}$ in a refrigerated dark room. Samples were next centrifuged at $4000 \mathrm{rpm}$ and the surface water transferred in the spectrophotometer for measurements. The Lorentzen method was then applied to calculate the chlorophyll a and phaeopigment concentration from absorbance measurements. The POC and C:N ratio were determined with a CARLO-ERBA analyser by the difference between SPM fixed on a GFF filter without treatment (total particulate carbon and nitrogen) and on acidified SPM samples (mineral carbon and nitrogen). Two replicates were made to examine the variability of the results. In addition, scanning electronic microscope (SEM) and optic microscope observations were made on samples at the start and the end of each flocculation test to identify floc constituents. 


\section{Results}

Results obtained at each station in the Seine estuary revealed the seasonal variability of the environmental conditions and the influence of such variability on flocculation efficiencies and kinetics. The latter parameters were flocculation efficiency $E_{\mathrm{f}}$ calculated as the ratio between the initial diameter $\left(D_{0}\right)$ and the final diameter measured at the end of the test $\left(D_{120}\right)$, the mean diameter of the ten largest flocs $D_{\max 10}$, flocculation speed $V_{f}$ and e-flocculation time $t_{\text {ef }}$. Experimental results were used to fit an empirical exponential model. The corresponding modelled diameter $\mathrm{D}_{\mathrm{am}}$ is:

$$
D_{a m}=D_{e}+\left(D_{0}-D_{e}\right) \mathrm{e}^{-\frac{\mathrm{t}}{\mathrm{tef}_{\mathrm{ef}}}}
$$

Where $\mathrm{D}_{0}$ is the initial mean diameter at $t=0 \mathrm{~s}, \mathrm{D}_{\mathrm{e}}$ is the steady-state diameter, and $t_{\mathrm{ef}}$ is the eflocculation time defined as:

$$
D_{a m}\left(t_{e f}\right)-D_{0}=\left(1-\frac{1}{e}\right)\left(D_{e}-D_{0}\right)
$$

A mean aggregation speed $V_{\mathrm{f}}$ is computed from the parameters of the model, $\mathrm{V}_{\mathrm{f}}$ is then given by:

$$
V_{f}=\frac{D_{e}-D_{0}}{t_{e f}}
$$

When the equilibrium state is not reached, $\mathrm{V}_{\mathrm{f}}$ is estimated from the difference between the initial diameter and the final diameter $\mathrm{D}_{120}$ obtained at the end of the 120 min experiments. Flocculation efficiency is the third parameter computed to characterize flocculation processes and corresponds to the ratio $\mathrm{D}_{120 /} \mathrm{D}_{0}$.

Total pigment concentrations were compared with measurements made during monthly surveys made by the Cellule Anti Pollution (CAP). Seasonal POC and total pigment 
concentrations are in agreement with results obtained by Etcheber et al. (2007) and Garnier et al. (2008) in the different compartments of the Seine Estuary.

\section{Fluvial estuary (station 1)}

Environmental conditions

No significant high river discharge periods occurred $\left(>1000 \mathrm{~m}^{3} \mathrm{~s}^{-1}\right)$ in the year when the measurements were made, and the surface SPM concentration never exceeded $0.05 \mathrm{~g} \mathrm{l}^{-1}$ (Fig. 4a). Time series of total pigment concentrations revealed two diatom blooms during spring 2004 (S1_0404 - peak and S1_0504 - end of bloom) and summer 2004 (S1_0804 - end of bloom) (Fig. 4b). These blooms were characterised by a $13 \mu \mathrm{m}$ diameter centric diatoms that are characteristic of freshwater diatoms observed in the Seine estuary (Lafite, 1990). During the most active period of the bloom, C:N values were below 8 (Fig 4c: S1_0404, S1_0305 and S1_0405). A diatom bloom that occurred during spring 2005 (S1_0305 and S1_0405) was characterised by its $\mathrm{C}: \mathrm{N}$ ratio (below 8 ) and POC values above $150 \mathrm{mgC} \mathrm{g}^{-1}$, which denotes a strong availability of labile organic matter. However, no measurements of pigment concentration were available for this period. During winter 2004, the total pigment concentration remained below $10 \mu \mathrm{g} \mathrm{l}^{-1}$, C:N values were as high as 10 but POC content nevertheless remained high ( $\left.100 \mathrm{mgC} \mathrm{g}^{-1}\right)$. The SPM was mainly comprised organo-mineral particles without significant diatoms (S1_1004 and S1_0105). No autumnal bloom was observed.

Flocculation experiments 
Kinetic experiments (Fig. 5) showed that flocculation occurred in freshwater environments, but were characterized by the flocculation efficiency $\left(E_{f}\right)$ of below 2 during the year. The diatom bloom in spring 2004 enhanced flocculation (S1_0404 and S1_0504), with E $\mathrm{f}_{\mathrm{f}}$ of 2.1 and 1.8 respectively (mean diameter of $140 \mu \mathrm{m}$ at equilibrium), and the highest $\mathrm{V}_{\mathrm{f}}$ values observed at this station (above $2 \mu \mathrm{m} \mathrm{min}^{-1}$ ). Flocculation processes were most intense during the period of diatom efflorescence, with a maximum $V_{\mathrm{f}}$ value of $8 \mu \mathrm{m} \mathrm{min}{ }^{-1}$, and a eflocculation time $t_{\mathrm{ef}}$ of $10 \mathrm{~min}$.

The spring bloom in 2005 (S1_0305 and S1_0405) did not display similar flocculation enhancements, with low $E_{f}$ values (below 1.5) and $D_{\max 10}$ values (below $140 \mu m$ ). This can be explained by comparing these results with SPM concentrations: S1_0405 (sampled during the most active period of the bloom in 2005) was characterized by a SPM concentration of 0.004 $\mathrm{g}^{-1}$ (Fig. 4a), which is the lowest concentration observed at this station. The maximum flocculation efficiency was observed during winter 2004, in the absence of bloom but with the highest SPM concentration $\left(\mathrm{C}_{\mathrm{SPM}}=0.016 \mathrm{~g} \mathrm{l}^{-1}\right)$. During autumn 2004 and winter 2004, the flocculation speed was under $2 \mu \mathrm{m} \mathrm{min}^{-1}$, which corresponds to $t_{\mathrm{ef}}$ values of more than 45 min. This result highlights the important role of SPM concentration in the efficiency of flocculation processes and the secondary but not negligible role of SPM organic matter content.

\section{Middle estuary (station 2)}

Environmental conditions

SPM mass concentrations observed at station 2 were significantly higher than those at station 1 with an annual average value of $0.05 \mathrm{~g} \mathrm{l}^{-1}$ (Fig. 6a). This trend was explained by the vicinity of the ETM (Fig. 1) as station 2 corresponded to the upstream extent of the ETM. Moreover, 
SPM quality at station 2 and 3 showed similar signatures in terms of $\mathrm{C}: \mathrm{N}$ ratios during winter 2004 and 2005 (Figs. 6c and 8c). Similar blooms occurred at stations 1 and 2 during spring 2004 and spring 2005 (Figs. 4b and 6b): therefore S2_0404, S2_0504 and S2_0804 as well as S2_0305 and S2_0405 are likely characteristic of diatom efflorescence. However, SPM samples showed lower POC content at station 2 compared with station 1 (below $80 \mathrm{mgC} \mathrm{g}^{-1}$ and an average value of $40 \mathrm{mgC} \mathrm{g}^{-1}$ ). This showed that the centre of the bloom was located upstream from station 2.

Flocculation experiments

The flocculation processes observed at station 2 displayed a similar dynamics to that obtained at station 1 (Figs. 5 and 7). Flocculation processes were enhanced during diatom blooms: S2_0404 corresponded to the experiment in which the flocculation rate was highest over the course of the studied years (2004-2005) and was correlated with the largest $D_{\max 10}(350 \mu \mathrm{m})$, and the highest flocculation speeds were observed at this station $\left(5.7 \mu \mathrm{m} \mathrm{min}{ }^{-1}\right.$, which corresponds to a $t_{\text {ef }}$ value of $25 \mathrm{~min}$ ). The S2_0305 kinetic test was performed during the onset of the spring bloom in 2005 when $\mathrm{C}_{\mathrm{SPM}}$ was the highest $\left(0.078 \mathrm{~g} \mathrm{l}^{-1}\right)$, and also displayed high $\mathrm{E}_{\mathrm{f}}$ and $\mathrm{V}_{\mathrm{f}}$ values (2.8 and $4.4 \mu \mathrm{m} \mathrm{min}^{-1}$ respectively). However, similarly to the dynamics observed at station 1, the influence of diatom blooms was strongly subordinated to SPM concentrations: the spring bloom in 2005 (S2_0405) corresponded to the lowest SPM mass concentration (10 $\mathrm{mg} \mathrm{l}^{-1}$ ) observed at station 2 and was characterized by low flocculation activity $\left(\mathrm{t}_{\mathrm{ef}}>60 \mathrm{~min}, \mathrm{E}_{\mathrm{f}}\right.$ of 2 and $\mathrm{V}_{\mathrm{f}}$ of $1.04 \mu \mathrm{m} \mathrm{min}^{-1}$ ). Autumn and winter 2004 (S2_0304, S2_1004 and S2_0105) were characterised by low flocculation activity, with typical flocculation speeds below $1.7 \mu \mathrm{m} \mathrm{min}^{-1}$, the lowest $\mathrm{E}_{\mathrm{f}}$ values $(1.7,1.5$ and 2.1 respectively) and lowest Dmax10 values (178, 146 and $240 \mu \mathrm{m}$ respectively). 


\section{Turbidity maximum (Station 3)}

\section{Environmental conditions}

SPM concentrations at station 3 were strongly influenced by the presence of the ETM and often exceeding the operational concentration for VIL observations (i.e. below $0.25 \mathrm{mg} \mathrm{l}^{-1}$ ). Therefore, samples were diluted in the laboratory to reach the operational VIL concentration. Final concentrations were always above $0.05 \mathrm{~g} \mathrm{l}^{-1}$, with three concentration peaks of more than $0.1 \mathrm{~g} \mathrm{l}^{-1}$ (Fig. 8a, S3_0304, S3_0404 and S3_0305). A major diatom bloom was observed in spring 2004 (S3_0404) which was closely correlated with the CAP dataset. However, the second bloom observed by CAP was not measured during S3_0804, and the quality of the measurements made during S3_1004 was poor and they were consequently not used. Like station 2, station 3 was characterized by $\mathrm{C}: \mathrm{N}$ values of 10 and a low average POC content of $50 \mathrm{mgC} \mathrm{g}^{-1}$. Due to high concentrations of SPM, grain size analysis revealed no specific modes that corresponded to diatoms, but diatoms were observed in SEM pictures.

Flocculation experiments

Kinetic experiments highlighted the influence of diatom blooms on flocculation processes (Fig. 9 S3_0404 and S3_0504, samples corresponding to the 2004 spring bloom), with a maximum of $\mathrm{V}_{\mathrm{f}}\left(6 \mu \mathrm{m} \min ^{-1}\right)$, high values of $\mathrm{D}_{\max 10}$ and $\mathrm{E}_{\mathrm{f}}(250 \mu \mathrm{m}$ and 2.6 respectively) and rapid flocculation (e-flocculation time $t_{\mathrm{ef}}<20 \mathrm{~min}$ ). The highest $\mathrm{E}_{\mathrm{f}}$ values were seen to correspond to the highest concentrations of SPM (S3_0404: $\mathrm{C}_{\mathrm{SPM}}=0.335 \mathrm{~g} \mathrm{l}^{-1}$ and S3_0305: $\mathrm{C}_{\mathrm{SPM}}=0.139 \mathrm{~g} \mathrm{l}^{-1}$ ). Winter and autumn periods displayed the dynamics similar to at stations 1 and 2. These periods correspond to the lowest flocculation activity, and were characterized by 
Verney, Lafite, Brun-Cottan -- 20

flocculation speeds of less than $1 \mu \mathrm{m} \min ^{-1}\left(\mathrm{t}_{\mathrm{ef}}>150 \mathrm{~min}\right), \mathrm{E}_{\mathrm{f}}$ values below 2 and $\mathrm{D}_{\max 10}$ values lower than $170 \mu \mathrm{m}$. 


\section{Discussion}

\section{$\underline{\text { Floc size measurements }}$}

Flocculation dynamics and floc sizes measurements are in good agreement with most of the in-situ measurements in similar environments. Nevertheless, they were smaller than the largest particles observed in situ (van Leussen, 1994; Eisma et al., 1996; Manning et al., 2004 among others). These differences could be explained by the different methods used to calculate floc sizes: the square-box diameter $\left(D_{\mathrm{SB}}\right)$, Feret diameter $\left(\mathrm{D}_{\mathrm{f}}\right)$, nominal elliptical diameter $\left(D_{e}\right)$ or the surface equivalent diameter $\left(D_{a}\right)$ (see material and methods section for a full description of these diameters). To evaluate their variability, characteristic sizes of three differently shaped flocs obtained with each method were compared (Table I): an elongated irregular floc (A), a large "round” (B), and a comet-shaped floc (C). Marked variations of up to $100 \%$ were observed. The square-box diameter $\mathrm{D}_{\mathrm{SB}}$ provided the largest size estimation of A and $C$, and was close to the largest of $B$. Unlike $D_{S B}$, the characteristic size $D_{a}$ used in this study, always gave the smallest estimated diameter. The largest differences were observed for the elongated floc, with differences ranging from 30 to 100\%. A global estimation of the differences between $D_{a}$ and $D_{f}$ or $D_{e}$ ranged from 20 to $30 \%$, which may explain the low estimation of the largest floc size compared with other studies.

Environmental parameters that influenced flocculation processes

Effect of turbulence 
The influence of turbulent structures on floc sizes was examined during the deflocculation experiments (Fig. 10). These measurements were also compared with other studies (Spicer and Pratsinis, 1996; Berhane et al., 1997; Manning and Dyer, 1999; Mikes et al., 2004). The maximum floc size (corresponding to the maximum length of the ellipse containing the floc) correlated well with the Kolmogorov microscale boundary (Fig 10A), confirming the control of the smallest turbulent vortices on the maximum floc size that can be observed in nature. No floc sizes exceed $\eta$, therefore flocs larger than $\eta$ are broken into fragments characterised by larger densities: circularity $C$ increases when $\mathrm{D}_{\mathrm{a}}$ decreases (Fig. 10B). It should be noted that this control is independent of the nature of the SPM and of its concentration.

Effect of salinity

The effect of variations in salinity on flocculation processes is a key issue. The influence of salinity on clay particle aggregation has been demonstrated, and corresponds to a threshold effect (Migniot, 1968; Thill et al., 2001). The effect on the macroflocculation of natural SPM is more questionable. Among other authors, Krone (1963) and Edzwald et al. (1974) stated that salinity is a dominant parameter that controls flocculation processes in coastal waters. Later, the role of salinity was downplayed by Eisma et al. (1991a, b) and Dyer (1986), who considered polysaccharides and biological/microbiological activity to be the most important flocculation enhancers. In this study, flocculation experiments carried out at $S=0$ and $S=20$ did not reveal a direct influence of salinity on floc growth (Fig. 11). Comparing the $D_{\max 10}$, $E_{f}$ and $V_{f}$ for both salinities revealed that salinity may enhance flocculation by increasing one of these parameters. However, data are globally scattered around the unity line, which shows similar flocculation dynamics for $S=0$ and $S=20$. In natural systems, salinity is associated with 
different environmental parameters such as SPM concentration or organic matter content. Thus, their direct effects on macrofloc sizes are not clear.

Effect of SPM features: investigation of the spatial and temporal variability in the Seine Estuary

Results obtained during the annual survey (Figs. 5, 7, 9) underlined the influence of SPM characteristics, typically SPM concentration and total pigment concentration, on flocculation potential. Comparison of flocculation parameters (flocculation efficiency $\mathrm{E}_{\mathrm{f}}$, flocculation speed $\mathrm{V}_{\mathrm{f}}$ ) with these two SPM characteristics (Fig. 12A) revealed that SPM concentration predominantly enhanced $E_{f}$ while total pigment concentration was correlated with $V_{f}$ : $E_{f}$ reached values of up to 2.5 for $C_{\text {SPM }}$ values above $0.060 \mathrm{~g} \mathrm{l}^{-1}$ and $V_{\mathrm{f}}$ increased up to $8 \mu \mathrm{m} \mathrm{min}{ }^{-}$ ${ }^{1}$ for a total pigment concentration of $80 \mu \mathrm{g} \mathrm{l}^{-1}$. It should be noted that even if flocculation processes are enhanced by high concentrations, aggregation was significant even at SPM concentrations as low as $0.01 \mathrm{~g} \mathrm{l}^{-1}$. The influence of SPM concentration is in agreement with the conceptual sketch of flocculation dynamics proposed by Dyer(1986), showing that floc diameter increases when $\mathrm{C}_{\text {SPM }}$ values increase up to values of several $\mathrm{g} \mathrm{l}^{-1}$. In the present study, the effect of concentration on potential flocculation enhancement was observed for concentrations of up to $\mathrm{C}_{\mathrm{SPM}}=0.350 \mathrm{~g} \mathrm{l}^{-1}$. Due to experimental limitations, the effect of larger SPM concentration was not investigated. However, in situ floc size measurements carried out in various estuaries in Europe and in the USA showed strong flocculation activity in ETM (Sanford et al., 2001; Uncles et al., 2006; Manning et al., 2006). Therefore the influence of SPM concentration on flocculation can be reasonably extended to the highest turbidity ( $\sim \mathrm{g} \mathrm{l}^{-}$ ${ }^{1}$ ) of the ETM of the Seine estuary. As SPM concentration increases seaward down to the ETM, flocculation activity would be expected to follow a similar trend. 
A seasonal effect superimposed on this spatial pattern was revealed, corresponding to the occurrence of diatom blooms in spring and autumn which strongly enhance flocculation processes and especially flocculation speed (i.e. reduced flocculation time) (Fig. 12B): during diatom blooms the flocculation speed was less than $40 \mathrm{~min}$ at all stations. This effect was observed all along the estuary, but was stronger in the upper estuary where concentrations were lowest: during spring 2004, during a diatom bloom at station 1, at similar concentrations (13 $\mathrm{mg} \mathrm{l}^{-1}$ ), flocculation efficiency increased by 15\%, flocculation speed doubled and flocculation time was the lowest: 10 min. However, flocculation activity was low when the SPM concentration was low (S1_0405 - spring 2005) even in the presence of a diatom bloom. This effect is related to the mucus or extracellular polymer substances secreted during diatom efflorescence and diatom assembly that all contribute to aggregation as gluing material or as component particles of flocs as illustrated in Figure 13.

The results obtained in our laboratory experiments were used to extrapolate the behaviour of SPM in the estuary. Results of turbulence measurements in the estuary (Fig. 3, Verney et al., 2006) showed that the time periods when $\eta>1000 \mu$ m (i.e. low turbulence periods) ranged from 1 hour (lower estuary at station 3) to 5 hours (upper estuary at station 1). These estimated time spans are compatible with e-flocculation times observed experimentally $\left(\mathrm{t}_{\mathrm{ef}}\right.$ below $100 \mathrm{~min}$ ) when there was significant aggregation. It can be assumed that aggregation can occur everywhere along the estuary, even in the upper estuary where concentrations are low, but mainly in the ETM where SPM concentrations are the highest. Moreover, flocculation processes would be accelerated during diatom blooms, and enhanced in the upper estuary where concentrations of SPM are low. However the laboratory experiments were not performed to reproduce the dynamic of particles in the water column at the tidal scale, as a consequence, further quantitative analysis cannot reasonably be addressed. 
Investigations of floc settling velocity

Floc settling velocities can theoretically be calculated from the fractal dimension, the floc size and the diameter of primary particles, according to the relationship given by Kranenburg (1994) (Eq. 6) and assuming Stokes law (van der Lee, 2000):

$$
w_{s}=\frac{g}{18 \mu}\left(\rho_{f}-\rho_{w}\right) D_{a}^{2}
$$

Where $\rho$ is the floc density estimated from Eq. $6, \rho_{\mathrm{w}}$ the water density and $D_{\mathrm{a}}$ is the diameter of flocs . Settling velocities were calculated from the mean floc size and the fractal dimension reached at the steady state of each flocculation test. Results are presented in Figure 14 and show an increase in settling velocity with floc size, from $0.07 \mathrm{~mm} \mathrm{~s}^{-1}$ to $0.5 \mathrm{~mm} \mathrm{~s}^{-1}$. These calculated values are lower than values measured directly in the Seine estuary or other estuaries (Fig. 14; Gibbs, 1985; Fennessy et al., 1994; van Leussen, 1994, Lafite, 2001). These discrepancies are explained by:

i) The choice of the characteristic diameter used to represent floc sizes as Da underestimates floc sizes of $30 \%$ and up to $100 \%$ compared with other methods.

ii) The population of flocs observed. In this study the mean floc size was considered to compute the characteristic settling velocity, whereas settling velocities observed on site often correspond to the largest particles, with the highest settling velocity.

iii) Uncertainty in the evaluation of the fractal dimension

iv) Choice of Stokes law with a constant water density value Indeed, the accurate choice of the value of fractal dimension is essential, as small variations in $\mathrm{n}_{\mathrm{f}}$ can cause large errors when calculating settling velocity. For example, the settling velocity of a $200 \mu \mathrm{m}$ particle changes from $0.16 \mathrm{~mm} \mathrm{~s}^{-1}$ to $0.34 \mathrm{~mm} \mathrm{~s}^{-1}$ for $\mathrm{n}_{\mathrm{f}}$ values of 1.62 and 1.82 respectively. Computing fractal dimension from 2D pictures is complex, and further 
experiments are necessary to examine this process and their consequences for floc settling more accurately. Therefore estimation of settling velocity must be carefully manipulated and in situ measurements are required for validation.

\section{$\underline{\text { Floc restructuring during flocculation experiments }}$}

During flocculation processes, particles collide with each other and aggregate. These processes increase the characteristic floc size and change the floc density (Chakraborti et al., 2003). This change in the shape and density of the particle was examined during a flocculation test conducted at station 3 (Fig. 15). At the beginning of the experiment, microflocs dominated; this explains the high $\mathrm{n}_{\mathrm{f}}$ value, which was close to 2. Rapidly, microflocs aggregated and formed macroflocs, which resulted in a sudden decrease in the fractal dimension down to 1.4, as also shown by (Chakraborti et al., 2003). Next, as flocculation continued, $\mathrm{n}_{\mathrm{f}}$ progressively increased up to values ranging from 1.8 to 1.9. These steady state values are representative of most of the flocculation experiments carried out from winter 2004 to spring 2005 and for the three stations. $\mathrm{n}_{\mathrm{f}}$ values ranged from 1.62 to 1.82 with a mean of 1.75 . These values are in agreement with other similar measurements (Logan and Wilkinson, 1990; Chen and Eisma, 1995), but are lower than the fractal dimensions calculated by comparing floc settling velocities and flocs sizes (i.e. 2.28, Fennessy et al., 1994; Manning and Dyer, 1999). These results demonstrate that flocs are subject to restructuring during aggregation by collecting microflocs. This is a challenging process as changes in fractal dimension are related to variations in floc densities and therefore have a strong effect on floc settling velocities. Changes in floc settling velocity over time calculated from mean floc size are presented in Figure 15. Floc settling velocities ranged from $0.05 \mathrm{~mm} \mathrm{~s}^{-1}$ at the beginning 
(microflocs dominates) of the test to $0.3 \mathrm{~mm} \mathrm{~s}^{-1}$ at steady state (mixed population of microflocs and macroflocs). 


\section{Conclusion}

We confirmed the ability of the VIL flocculator based on the jar-test technique to perform repetitive flocculation experiments and to reproduce turbulence parameters close to those observed in estuarine waters. The use of a CCD camera allowed high quality image acquisition, providing both characteristic floc sizes and shape factors (i.e. fractal dimension and circularity). A comparison between floc measurements from different studies revealed a bias related to the method used to calculate floc sizes, and that the diameters of flocs observed from the surface were 20 to $30 \%$ lower than Feret lengths or than the nominal elliptical diameter.

Flocculation experiments carried out using material sampled every two months from February 2004 to May 2005 at three stations in the Seine estuary enabling investigation of the influence of SPM quality (SPM concentration, total pigment concentration, POC content, C:N ratio) on flocculation processes. The empirical exponential model applied to the experimental results provided key parameters such as flocculation efficiency, e-flocculation time and flocculation speed to examine the relationship between environmental conditions and flocculation. Results revealed that aggregation occurs in freshwater with low SPM concentrations $(<0.05 \mathrm{~g}$

$\mathrm{l}^{-1}$ ) in natural systems. They highlighted the effective control of diatom blooms and SPM concentration on floc growth kinetics, as these two parameters enhance flocculation speed and flocculation efficiency respectively. Compared to these two factors, salinity appeared to be a control parameter of secondary importance whose effects are not very clear. The intensity of turbulence was seen to control the maximum floc size by breaking down flocs larger than the size of the smallest turbulent vortices measured by the Kolmogorov microscale. 
Examination of variations in the fractal dimension during flocculation tests revealed a restructuring of the floc characterized by a rapid decrease from 2 to 1.4 due to the first particle aggregations in the first minutes of flocculation, then $\mathrm{n}_{\mathrm{f}}$ increased up to a steady state, which varied from 1.62 to 1.82 in all tests. 


\section{Acknowledgments}

Funding for this study was partly provided by the European INTERREG III RIMEW programme and the Seine Aval Program. Romaric Verney was funded through a grant provided by the Regional Council of Haute Normandie (France). We would like to thank Mrs Irene Zimmerlin for her work on SEM observations. 


\section{Literature cited}

Alldredge, A. L., C. Gotschalk, U. Passow and U. Riebesell. 1995. "Mass aggregation of diatom blooms: Insights from a mesocosm study." Deep-Sea Research II 42(1):9-27.

Avoine, J. 1981. Estuaire de la Seine: sédiments et dynamique sédimentaire, Université de Caen: 236p.

Avoine, J. 1986. Evaluation des apports fluviatiles dans l'estuaire de la Seine. La baie de Seine (GRECO MANCHE), Caen, Ifremer.

Berhane, I., R. W. Sternberg, G. C. Kineke, T. G. Milligan and K. Kranck. 1997. "The variability of suspended aggregates on the Amazon Continental Shelf." Continental Shelf Research 17(3):267-285.

Billiones, R. G., M. L. Tackx and M. H. Daro. 1999. "The geometric features, shape factors and fractal dimensions of suspended particulate matter in the Scheldt Estuary (Belgium)." Estuarine, Coastal and Shelf Science 48:293-305.

Chakraborti, R. K., K. H. Gardner, J. F. Atkinson and J. E. Van Benschoten. 2003. "Changes in fractal dimension during aggregation." Water Research 37(4):873-883.

Chen, S. and D. Eisma. 1995. "Fractal geometry of in-situ flocs in the estuarine and coastal environments." Netherlands Journal of Sea Research 32(2):173-182. 
Dobereiner, C. and J. P. McManus. 1983. "Turbidity maximum migration and harbour siltation in the Tay Estuary." American Journal of Fish Aquatic Science Supplement 40:117129.

Dupont, J.-P. 2001. Matériaux fins : le cheminement des particules en suspension. Programme Scientifique Seine Aval, Programme Scientifique Seine Aval: 39p.

Dyer, K. R. 1986. Coastal and estuarine sediment dynamics. Chichester, J. Wiley and Sons.

Edzwald, J. K., J. B. Upchurch and C. R. O'Melia. 1974. "Coagulation in estuaries." Environmental Science and Technology 8:58-63.

Eisma, D. 1993. Suspended matter in the aquatic environment, Springer-Verlag.

Eisma, D., A. J. Bale, M. P. Dearnaley, M. J. Fennessy, W. van Leussen, M.-A. Maldiney, A. Pfeiffer and J. T. Wells. 1996. "Intercomparison of in-situ suspended matter (floc) size measurement." Journal of Sea Research 36(1/2):3-14.

Eisma, D., P. Bernard, G. C. Cadée, V. Ittekkot, J. Kalf, R. Laane, J. M. Martin, W. G. Mook, A. van Put and T. Schumacher. 1991a. "Suspended matter particle size in some west european estuaries; Part I: Particle size distribution." Netherlands Journal of Sea Research 28(3):193214. 
Eisma, D., P. Bernard, G. C. Cadée, V. Ittekkot, J. Kalf, R. Laane, J. M. Martin, W. G. Mook, A. van Put and T. Schumacher. 1991b. "Suspended-matter particle size in some westeuropean estuaries; Part II: a review on floc formation and break-up." Netherlands Journal of Sea Research 28(3):215-220.

Eisma, D., J. D. Boon, R. Groenewegen, V. Ittekkot, J. Kalf and W. G. Mook. 1983.

"Observations on macro-aggregates, particle size and organic composition of suspended mater in the Ems Estuary."

Fennessy, M. J., K. R. Dyer and D. A. Huntley. 1994. "INSSEV: an instrument to measure the size and settling velocity of flocs in situ." Marine geology 117:107-117.

Flory, E. N., P. S. Hill, T. G. Milligan and J. Grant. 2004. "The relationship between floc area and backscatter during a spring phytoplankton bloom." Deep-Sea Research I 51:213-223.

Gibbs, R. J. 1985. "Estuarine flocs: their size, settling velocity and density." Journal of Geophysical Research 90(C2):3249-3251.

Guezennec, L. 1999. Hydrdynamique et transport en suspension du matériel particulaire fin dans la zone fluviale d'un estuaire macrotidal : l'exemple de l'estuaire de la Seine (France). Université de Rouen: 240p.

Jarvis, P., B. Jefferson, J. Gregory and S. A. Parsons. 2005. "A review of floc strength and breakage." Water Research 39(14):3121-3137. 
Kranenburg, C. 1994. "The fractal structure of cohesive sediment aggregates." Estuarine, Coastal and Shelf Science 39:451-460.

Kranenburg, C. 1999. "Effects of floc strength on viscosity and deposition of cohesive sediment suspensions." Continental Shelf Research 19:1665-1680.

Krone, R. B. 1963. A study of rheologic properties of estuarial sediments. Technical Bulletin 7. Vicksburgh, MS, USAE Communication on Tidal Hydrodynamics.

Lafite, R. 1990. Caractérisation et dynamique des particules en suspension dans un domaine marin macrotidal influencé par un estuaire : l'exemple de la baie de Seine orientale (France). Geologie. Rouen, Université de Rouen: 294p.

Lafite, R. 2001. Impact de la dynamique tidale sur le transfert de sédiments fins, Université de Rouen: 80p.

Le Hir, P., A. Ficht, R. Silva Jacinto, P. Lesueur, J.-P. Dupont, R. Lafite, I. Brenon, B. Thouvenin and P. Cugier. 2001. "Fine sediment transport and accumulations at the mouth of the Seine Estuary (France)." Estuaries 24(6B):950-963.

Lesourd, S. 2000. Processus d'envasement d'un estuaire macrotidal: zoom temporel du siècle à l'heure; application à l'estuaire de la Seine. Caen, Université de Caen: 290p.

Logan, B. E. and D. B. Wilkinson. 1990. "Fractal geometry of marine snow and other biological aggregates." Limnology and Oceanography 35:130-136. 
Lunau, M., A. Lemke, O. Dellwig and M. Simon. 2006. "Physical and biogeochemical controls of microaggregates dynamics in a tidally affected coastal ecosystem." Limnology and Oceanography 51(2):847-859.

Maggi, F. 2005. Flocculation dynamics of cohesive sediment. Faculty of Civil Engineering and Geosciences. Delft, PhD Thesis, University of Technology, Delft: 136p.

Manning, A. J. and K. R. Dyer. 1999. "A laboratory examination of floc characteristics with regard to turbulent shearing." Marine Geology 160:147-170.

Manning, A. J., K. R. Dyer, R. Lafite and D. Mikes. 2004. "Flocculation measured by video based instruments in the Gironde estuary during the european commission SWAMIEE Project." Journal of coastal research 41:59-69.

Meakin, P. 1988. "Models for colloidal aggregation." Ann. Rev. phys. Chem. 39:237-267.

Migniot, C. 1968. "Etude des propriétés physiques de différents sédiments très fins et de leur comportement sous des actions hydrodynamiques." La Houille Blanche 7:591-619.

Mikes, D., R. Verney, R. Lafite and M. Belorgey. 2004. "Controlling factors in estuarine flocculation processes : experimental results with material from the Seine Estuary, Northwestern France." Journal of coastal research 41:82-89. 
Milligan, T. G. and Hill, P. S. (1998). "A laboratory assessment of the relative importance of turbulence, particle composition, and concentration in limiting maximal floc size and settling behaviour." Journal of Sea Research 39: 227-241

Passow, U. and A. L. Alldredge. 1995. "Aggregation of a diatom bloom in a mesocosm : the role of transparent exopolymer particles (TEP)." Deep-Sea Research II 42(1):99-109.

Sanford, L. P., Syttles, S. E. and Halka, J. P. (2001). "Reconsidering the physics of the Chesapeake Bay estuarine turbidity maximum." Estuaries 24(5): 655-669.

Spicer, P. T. and S. E. Pratsinis. 1996. "Shear-induced flocculation: the evolution of floc structure and the shape of the size distribution at steady state." Water Research 30(5):10491056.

Sternberg, R. W., I. Berhane and A. S. Ogston. 1999. "Measurement of size and settling velocity of suspended aggregates on the Northern California contiental shelf." Marine Geology 154:43-53.

Thill, A., S. Moustier, J.-M. Garnier, C. Estournel, J.-J. Naudin and J.-Y. Bottero. 2001. "Evolution of particle size and concentration in the Rhone river mixing zone: influence of salt flocculation." Continental Shelf Research 21:2127-2140.

Uncles, R. J., J. A. Stephens and D. J. Law. 2006. "Turbidity maximum in the macrotidal, highly turbid Humber Estuary, UK : Flocs, fluid mud, stationary suspensions and tidal bores." Estuarine, Coastal and Shelf Science xx:1-23. 
Van der Lee, W. (2000). "Temporal variation of floc size and settling velocity in the Dollard Estuary." Continental Shelf Research 20: 1495-1511.

van Leussen, W. 1994. Estuarine macroflocs : their role in fine grained sediment transport. Utrecht, University of Utrecht: 488p.

Verney, R. 2006. Processus de contrôle de la dynamique des sédiments cohésifs. UMR 6143 M2C, Université de Rouen: 325.

Verney, R., J. C. Brun Cottan, R. Lafite, J. Deloffre and J. A. Taylor. 2006. "Tidally-induced shear stress variability above intertidal mudflats. Case of the macrotidal Seine estuary." Estuaries and Coasts 29(4):653-664.

Winterwerp, J. C. (2006). "A heuristic formula for turbulence-induced flocculation of cohesive sediment." Estuarine, Coastal and Shelf Science 68: 195-207. 


\section{Figure legends}

Figure 1: The Seine estuary: main compartments and sampling stations

Figure 2: Description of the ‘Video In Lab’ (VIL) device

Figure 3: Hydrodynamic conditions in the Seine estuary at 2 stations during a full tidal period. Results from in situ measurements (kp 230 for the fluvial estuary and kp 335 for the middle estuary) during neap tide and spring tide conditions (Verney et al., 2006). Time series of current velocity (A) and Kolmogorov microscale (B) values. Occurrence distribution (C) and Cumulative occurrence distribution (D) of the Kolmogorov microscale values; the latter are compared with Kolmogorov microscale values obtained from VIL calibration by LDV measurements for defined rotation speeds $(\omega)$.

Figure 4: Time series of suspended particulate matter parameters at station 1 (Rouen, kp 245): SPM concentration, total pigment concentration, POC and C:N values. Total pigment concentrations are compared with monthly measurements made by the Cellule Anti Pollution.

Figure 5: Flocculation ability of SPM sampled at station 1 (Rouen, kp 245): changes in flocculation efficiency $\left(\mathrm{E}_{\mathrm{f}}\right)$, flocculation speed $\left(\mathrm{V}_{\mathrm{f}}\right)$, e-flocculation time $\left(\mathrm{t}_{\mathrm{ef}}\right)$ and sizes of the ten largest flocs $\left(\mathrm{D}_{\max 10}\right)$.

Figure 6: Time series of suspended particulate matter parameters at station 2 (Caudebec en Caux, kp 310): SPM concentration, total pigment concentration, POC and C:N values. Total 
pigment concentrations are compared with monthly measurements made by the Cellule Anti Pollution

Figure 7: Flocculation ability of SPM sampled at station 2 (Caudebec en Caux, kp 310): changes in flocculation efficiency $\left(\mathrm{E}_{\mathrm{f}}\right)$, flocculation speed $\left(\mathrm{V}_{\mathrm{f}}\right)$, e-flocculation time $\left(\mathrm{t}_{\mathrm{ef}}\right)$ and sizes of the ten largest flocs $\left(D_{\max 10}\right)$.

Figure 8: Time series of suspended particulate matter parameters at station 3 (Tancarville, kp 335): SPM concentration, total pigment concentration, POC and C:N values. Total pigment concentrations are compared with monthly measurements made by the Cellule Anti Pollution. The question mark indicates uncertainty about the quality of this sample

Figure 9: Flocculation ability of SPM sampled at station 3 (Tancarville, kp 335): changes in flocculation efficiency $\left(\mathrm{E}_{\mathrm{f}}\right)$, flocculation speed $\left(\mathrm{V}_{\mathrm{f}}\right)$, flocculation time $\left(\mathrm{t}_{\mathrm{ef}}\right)$ and sizes of the ten largest flocs $\left(\mathrm{D}_{\max 10}\right)$

Figure 10: Examination of the effect of turbulence on flocculation processes. A: Comparison of maximum floc sizes and Kolmogorov microscale values; B: Changes in the flocs' circularity

Figure 11: Effect of salinity on flocculation: comparison of flocculation parameters for $S=0$ and $\mathrm{S}=20$ kinetic experiments. 
Figure 12: Influence of SPM concentration and diatom blooms on flocculation processes: comparison between SPM concentration and floc efficiency (A) and total pigment concentration and flocculation speed (B)

Figure 13: SEM picture illustrating of the role of diatoms in aggregation processes (picture taken after a flocculation test from SPM collected in spring at station 1)

Figure 14: Comparison between floc size and floc settling velocity. A: Settling velocity calculated from the mean floc size and the fractal dimension at the end of the 2-hour tests. B: Comparison with settling velocity measurements performed in various estuaries.

Figure 15: Floc restructuring during flocculation: variations in floc sizes $D_{a}$, 2D fractal dimension $\mathrm{n}_{\mathrm{f}}$ and computed settling velocity $\mathrm{w}_{\mathrm{s}}$

Table I: Comparison of characteristic floc sizes calculated for three different shaped flocs. 
Figure 1

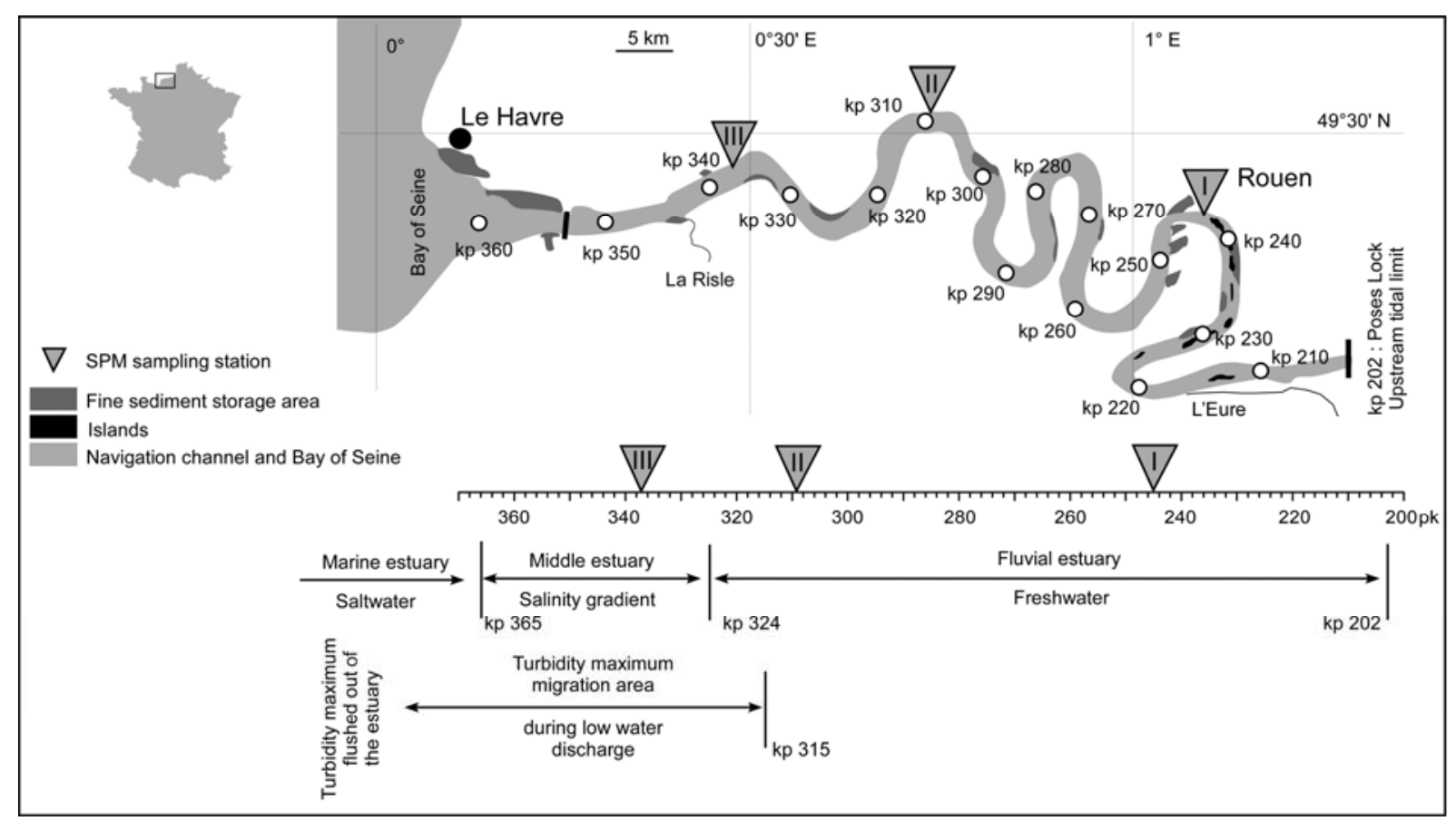


Figure 2

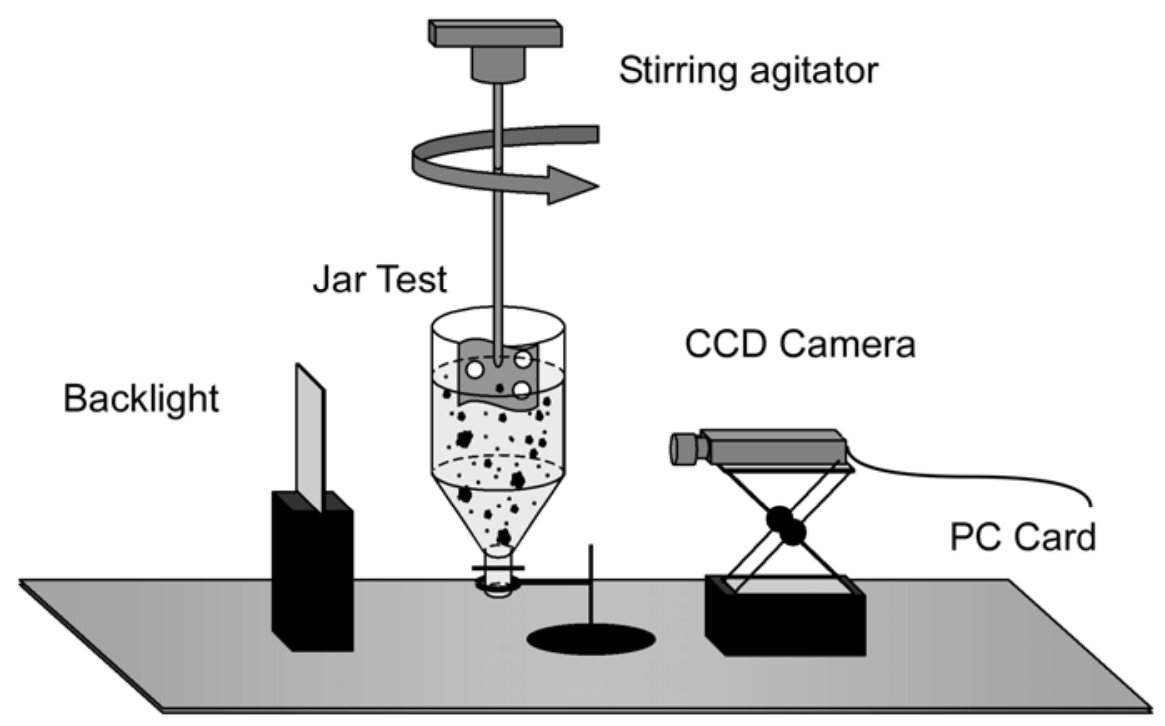


Figure 3
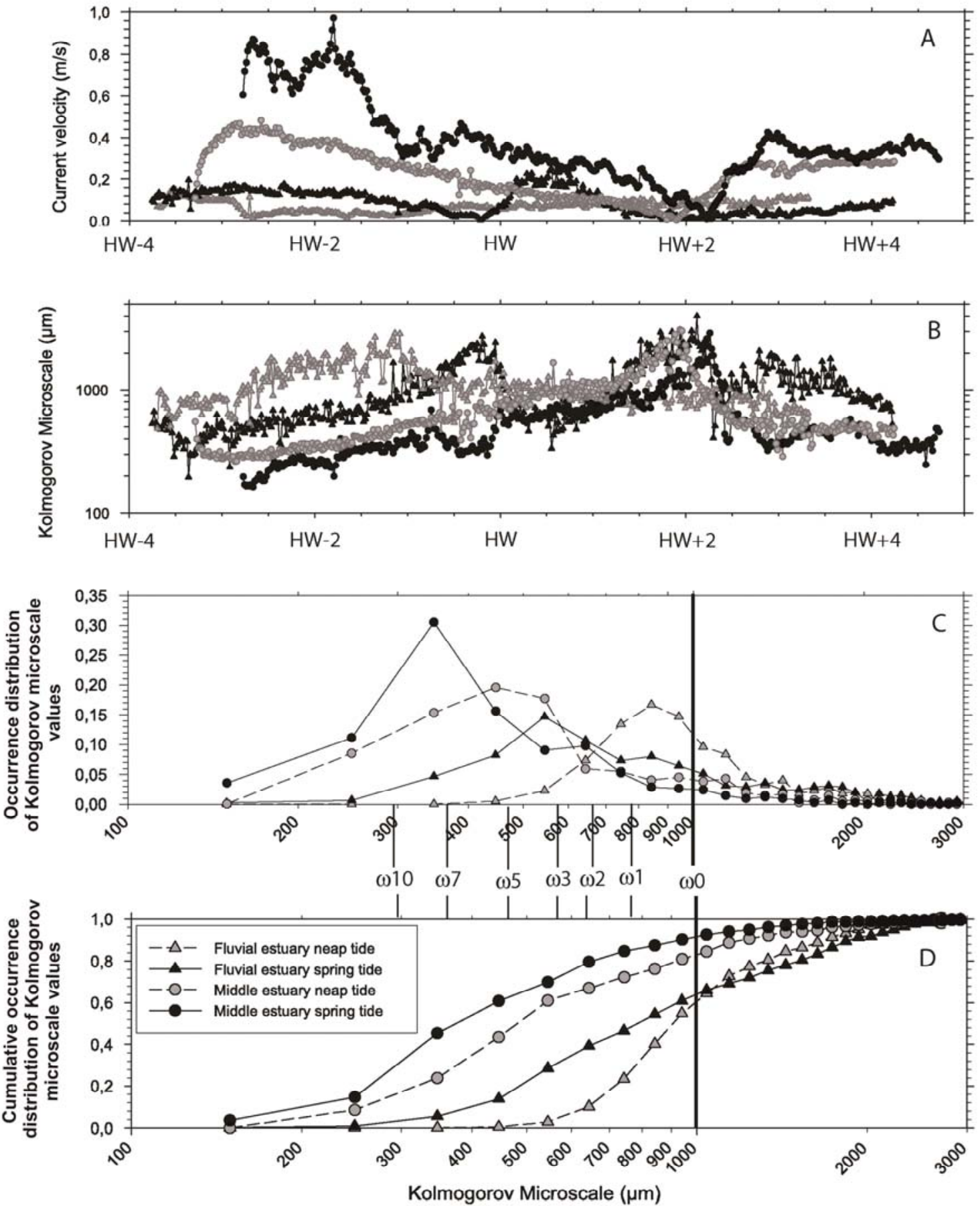
Figure 4
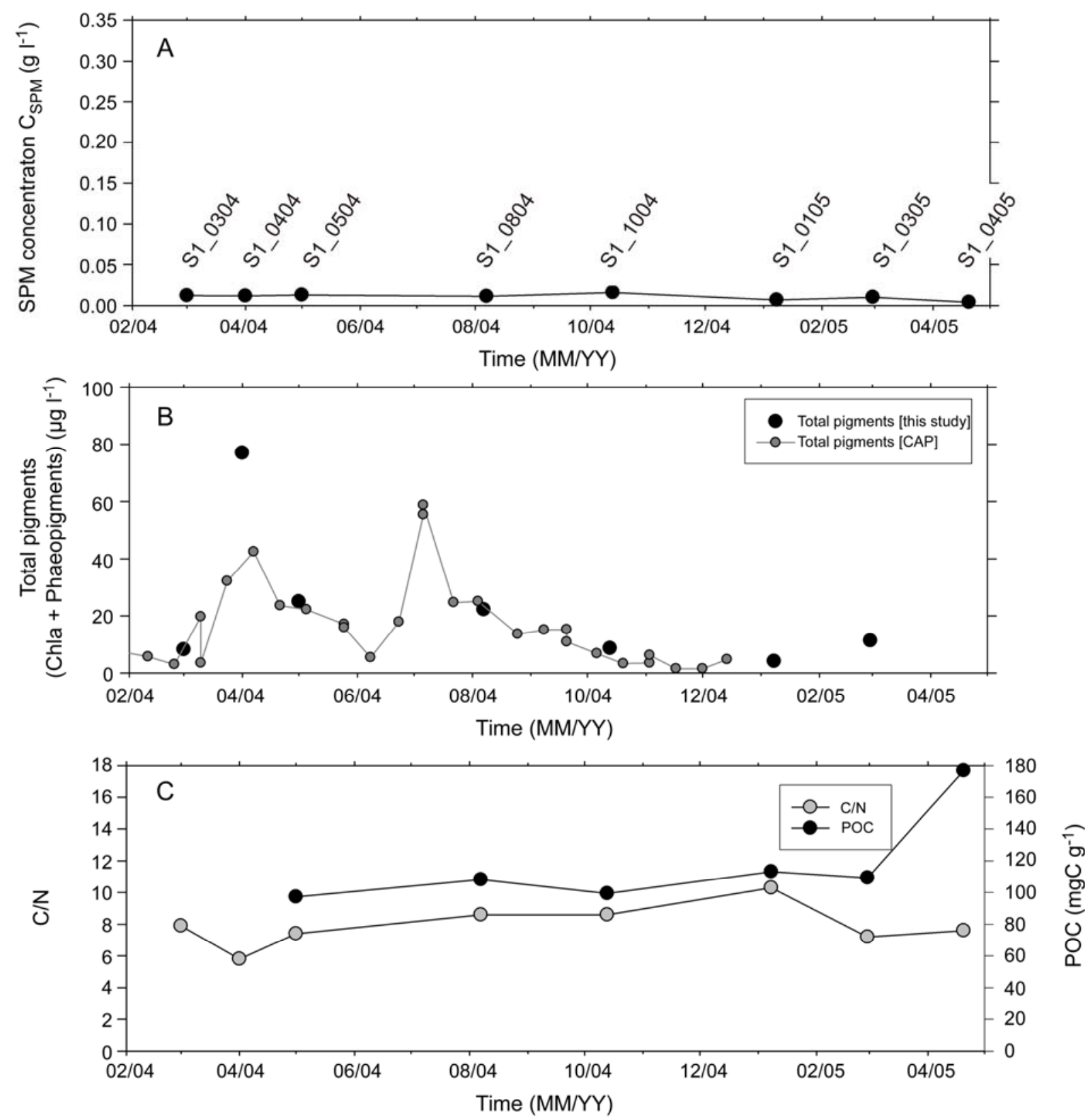
Figure 5

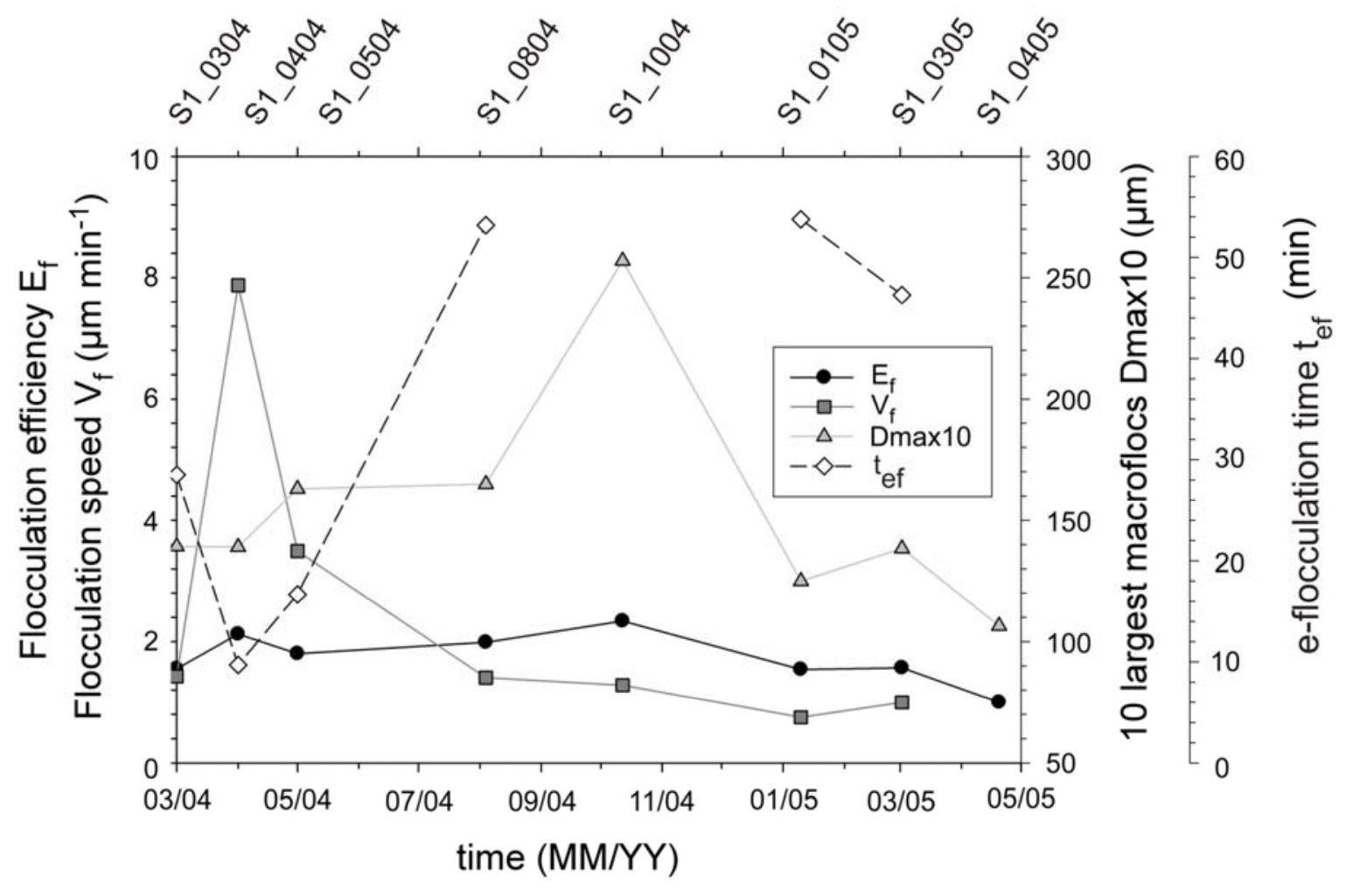


Figure 6
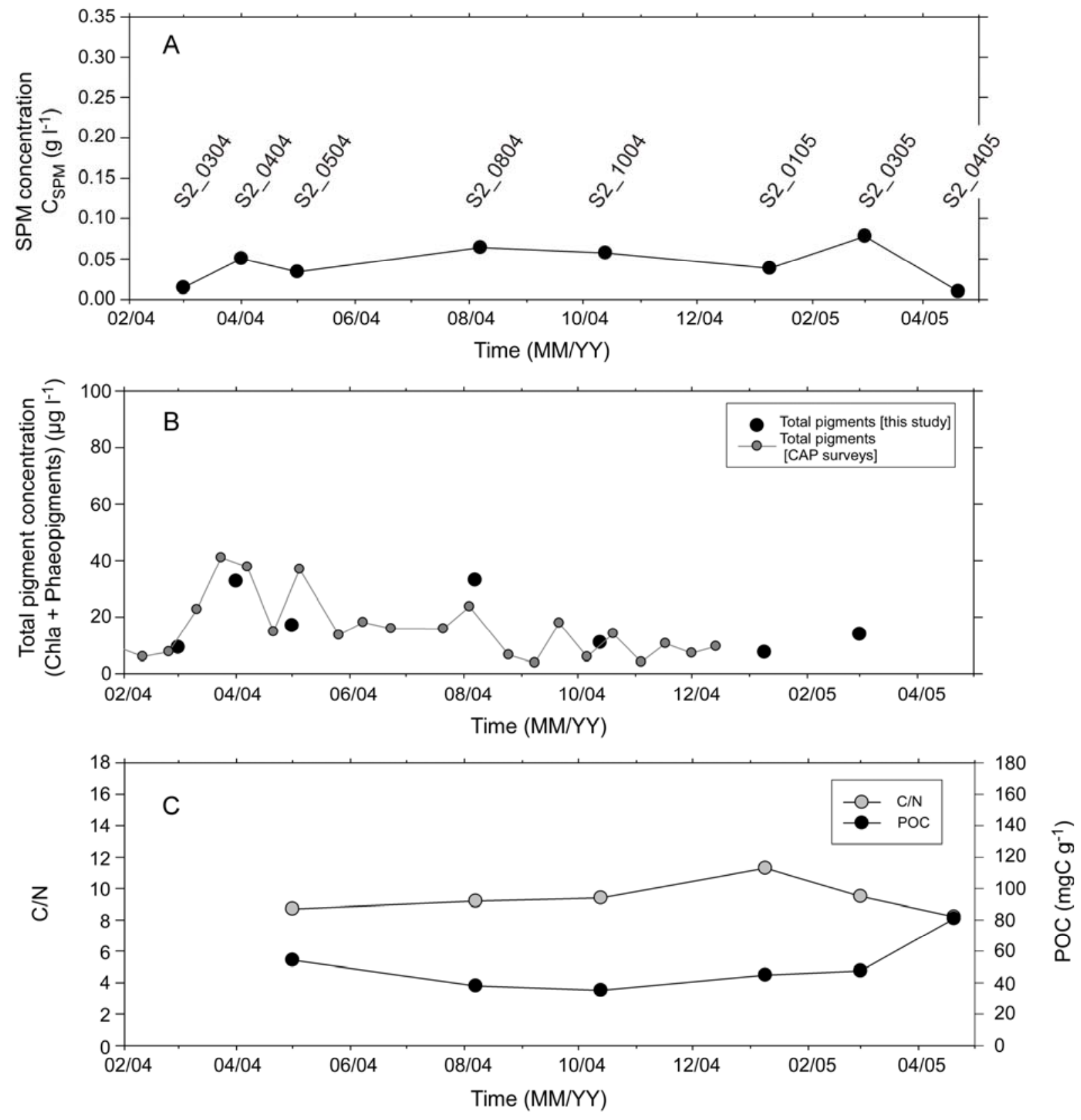
Figure 7

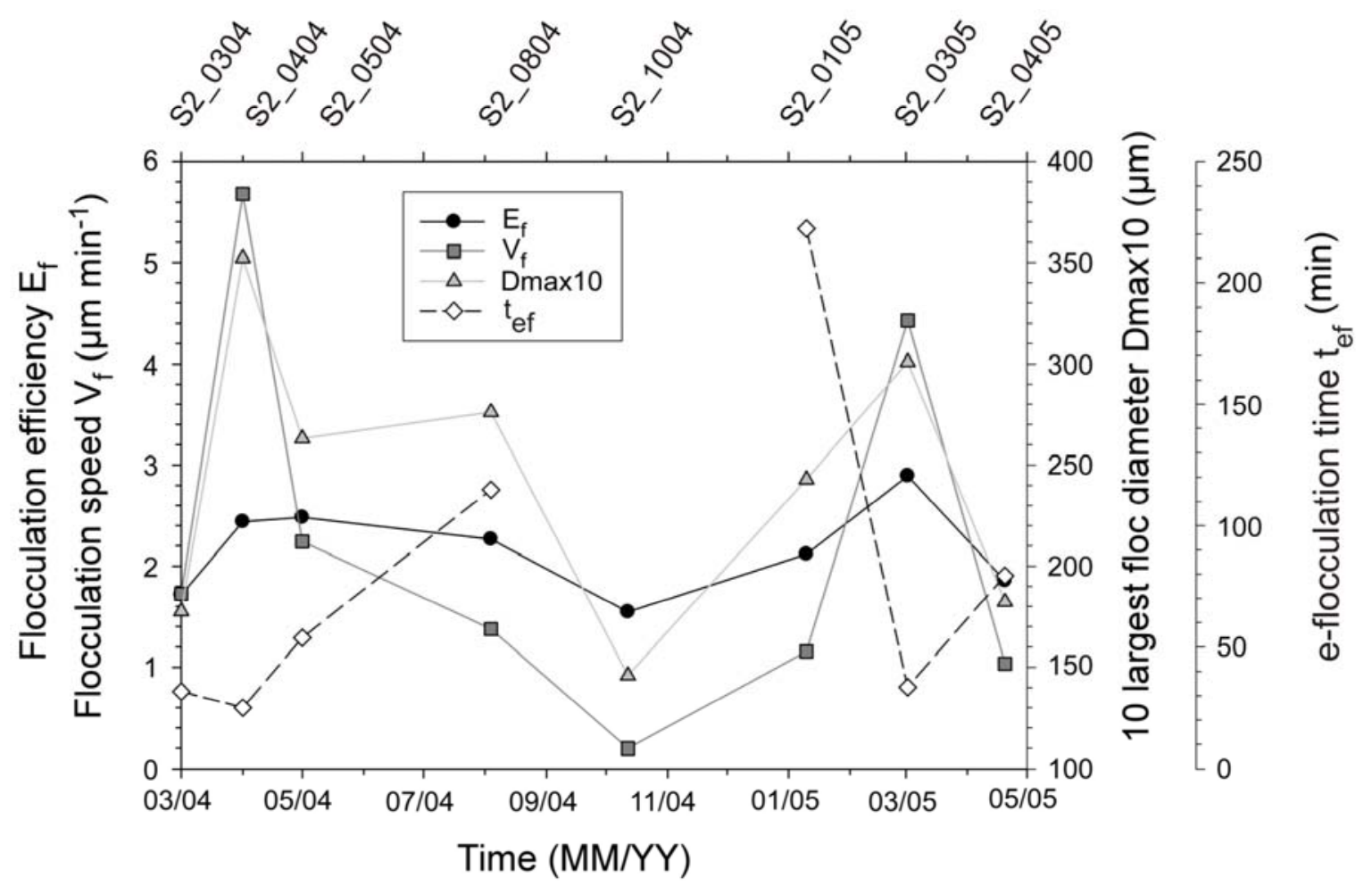


Figure 8
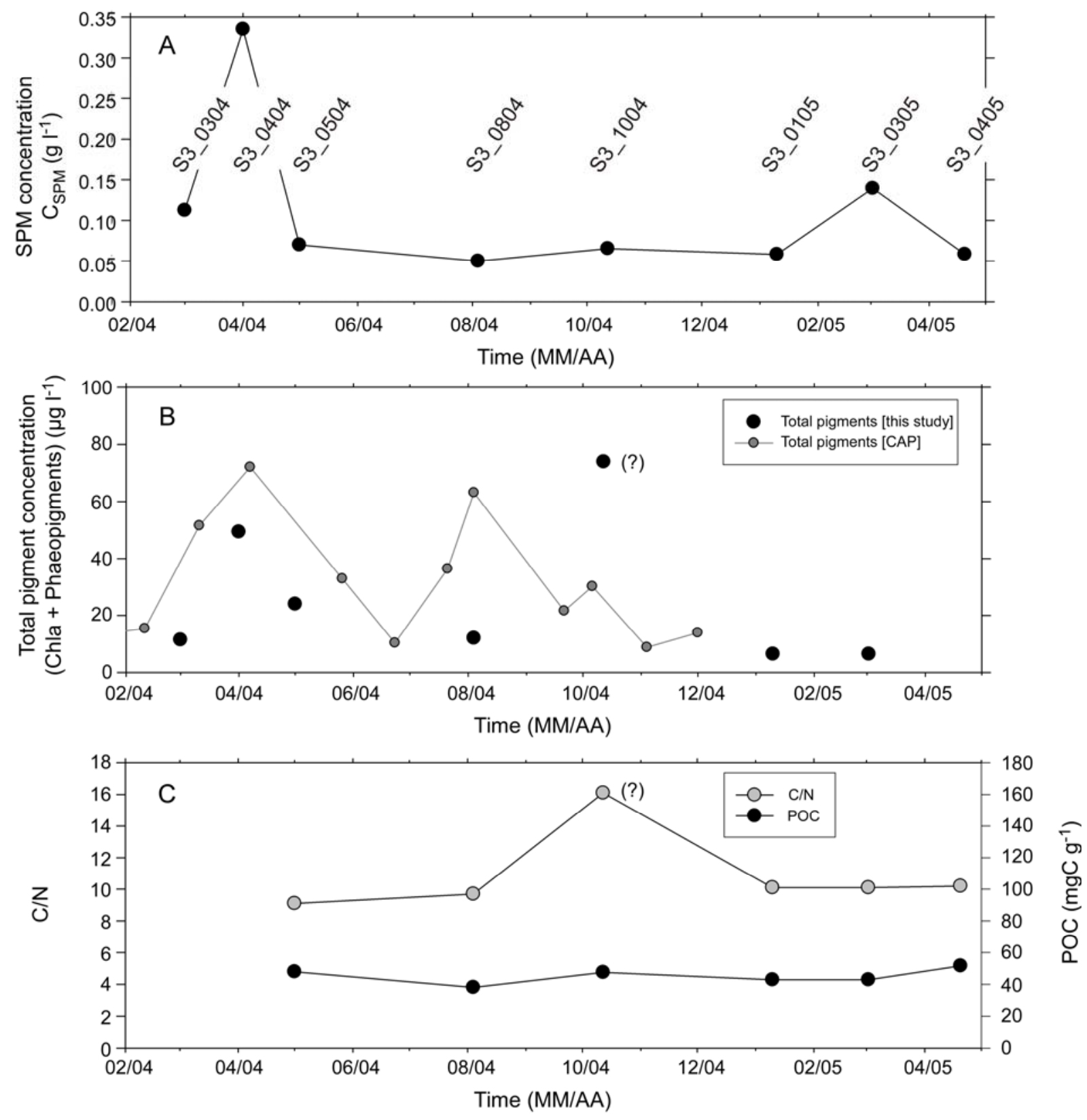
Figure 9

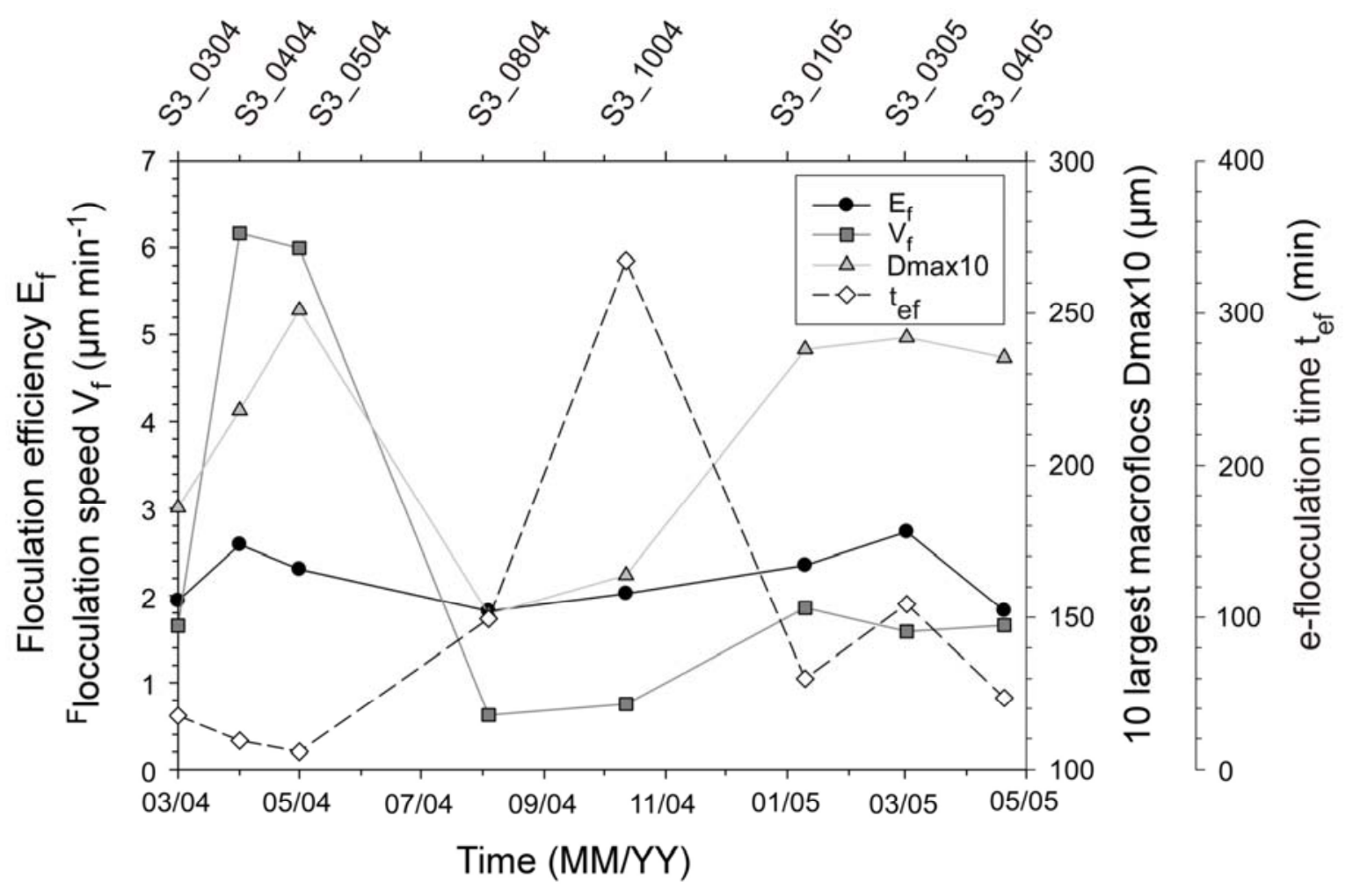


Figure 10
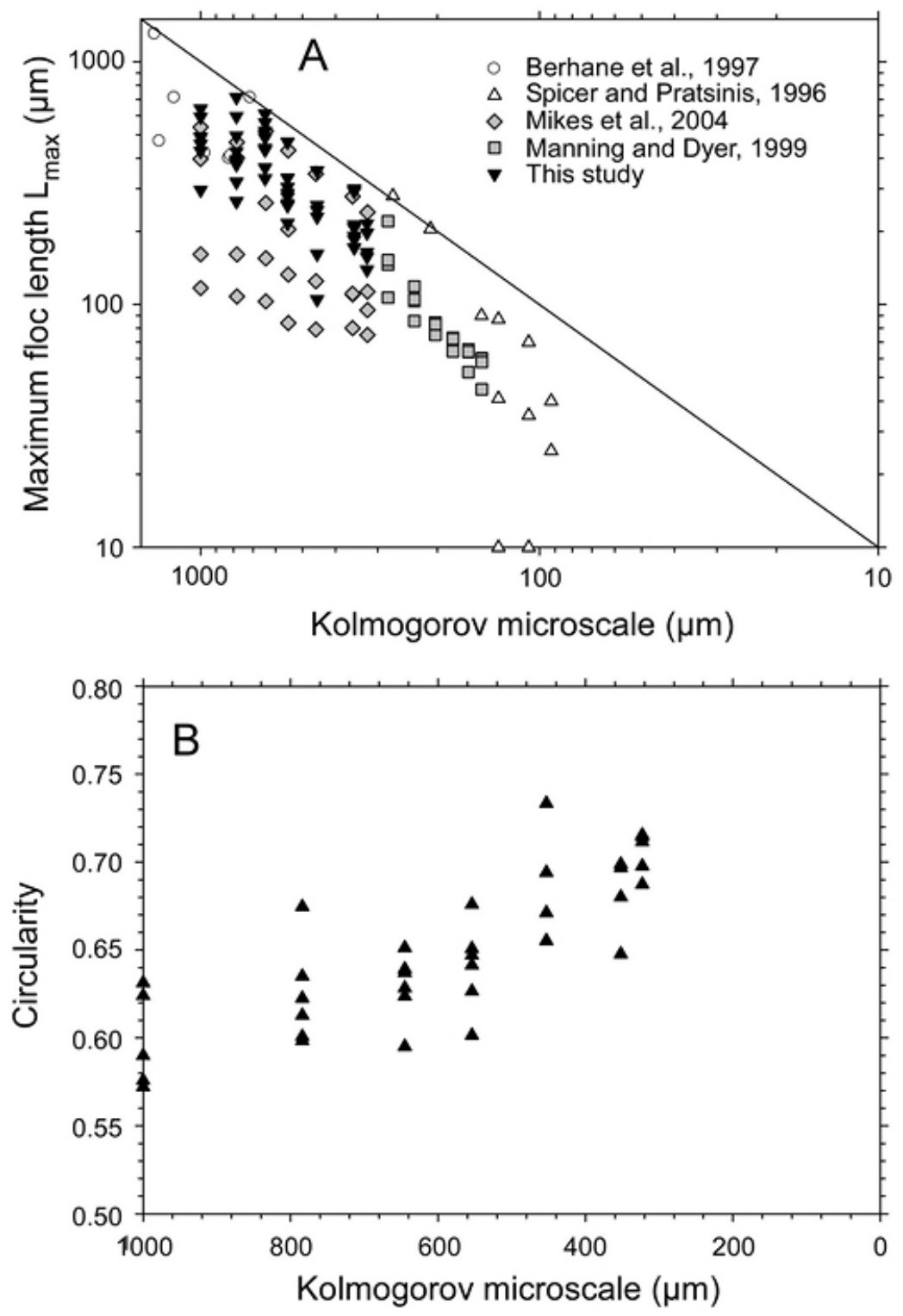
Figure 11

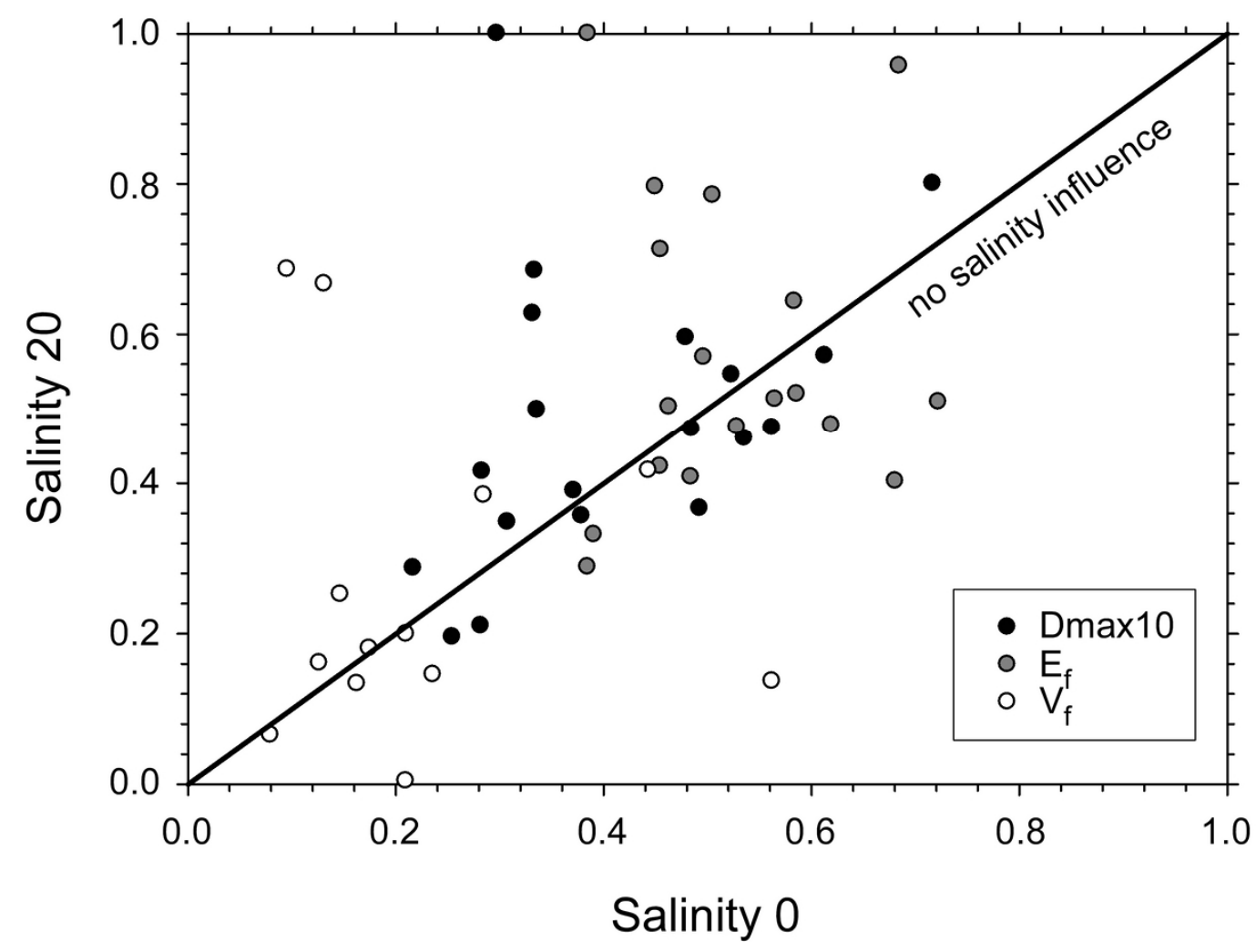


Verney, Lafite, Brun-Cottan -- 52

Figure 12 

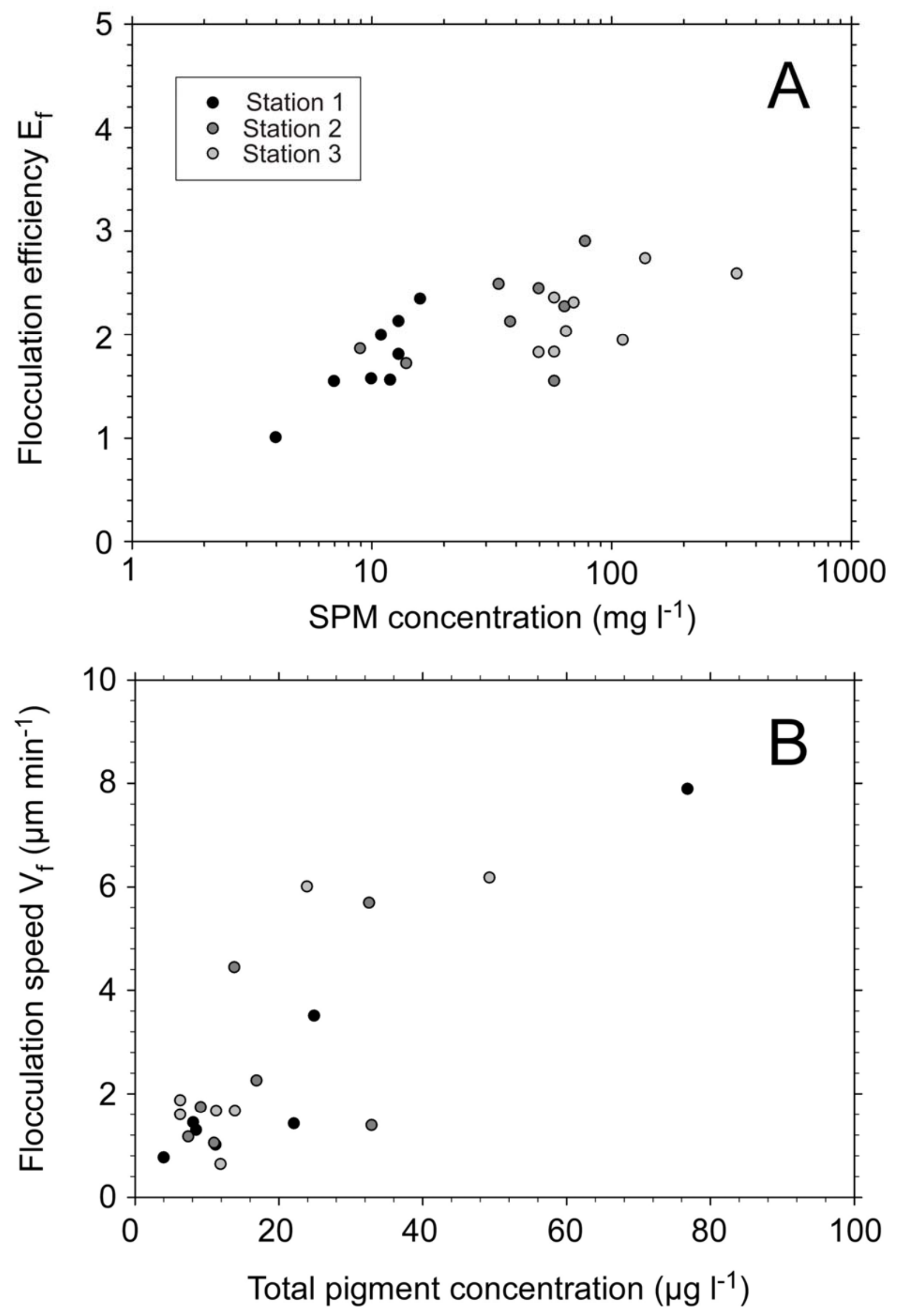
Verney, Lafite, Brun-Cottan -- 54 
Verney, Lafite, Brun-Cottan -- 55

Figure 13

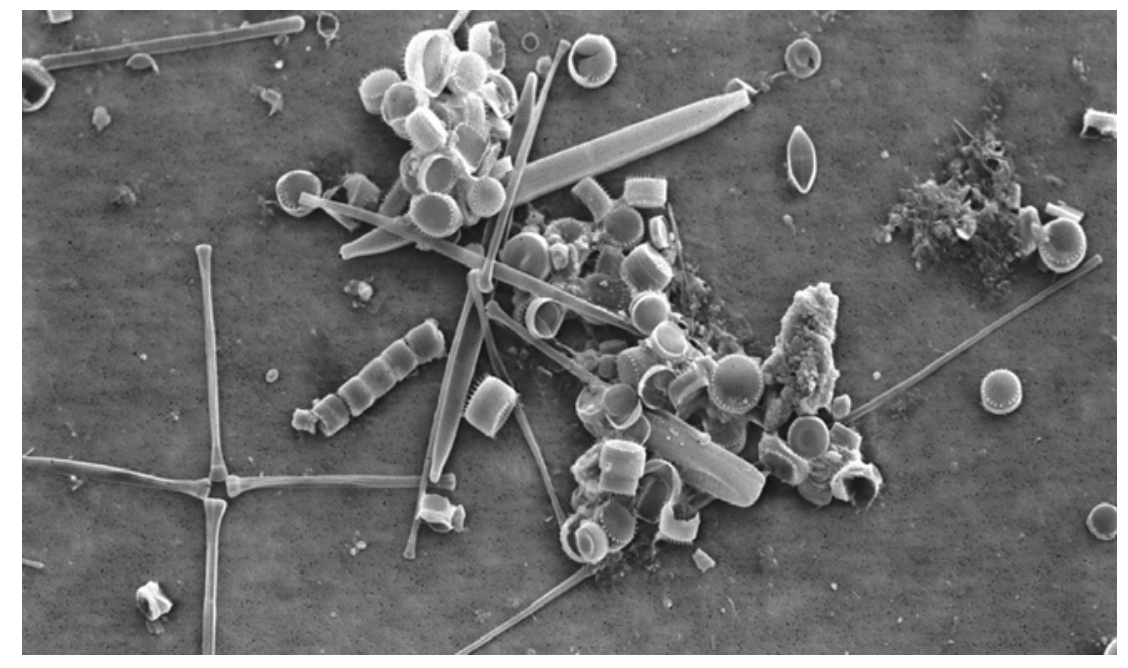


Figure 14
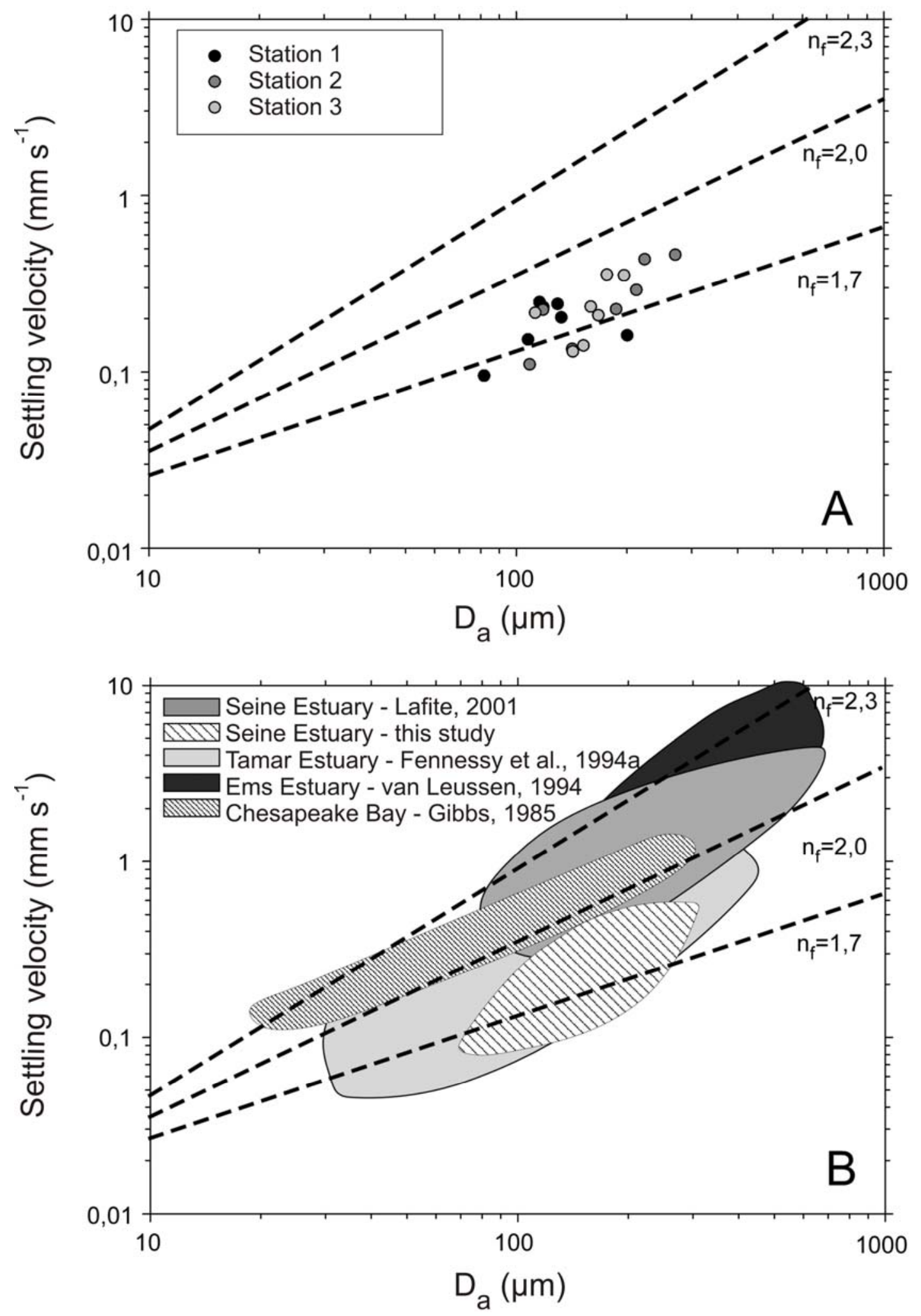
Figure 15

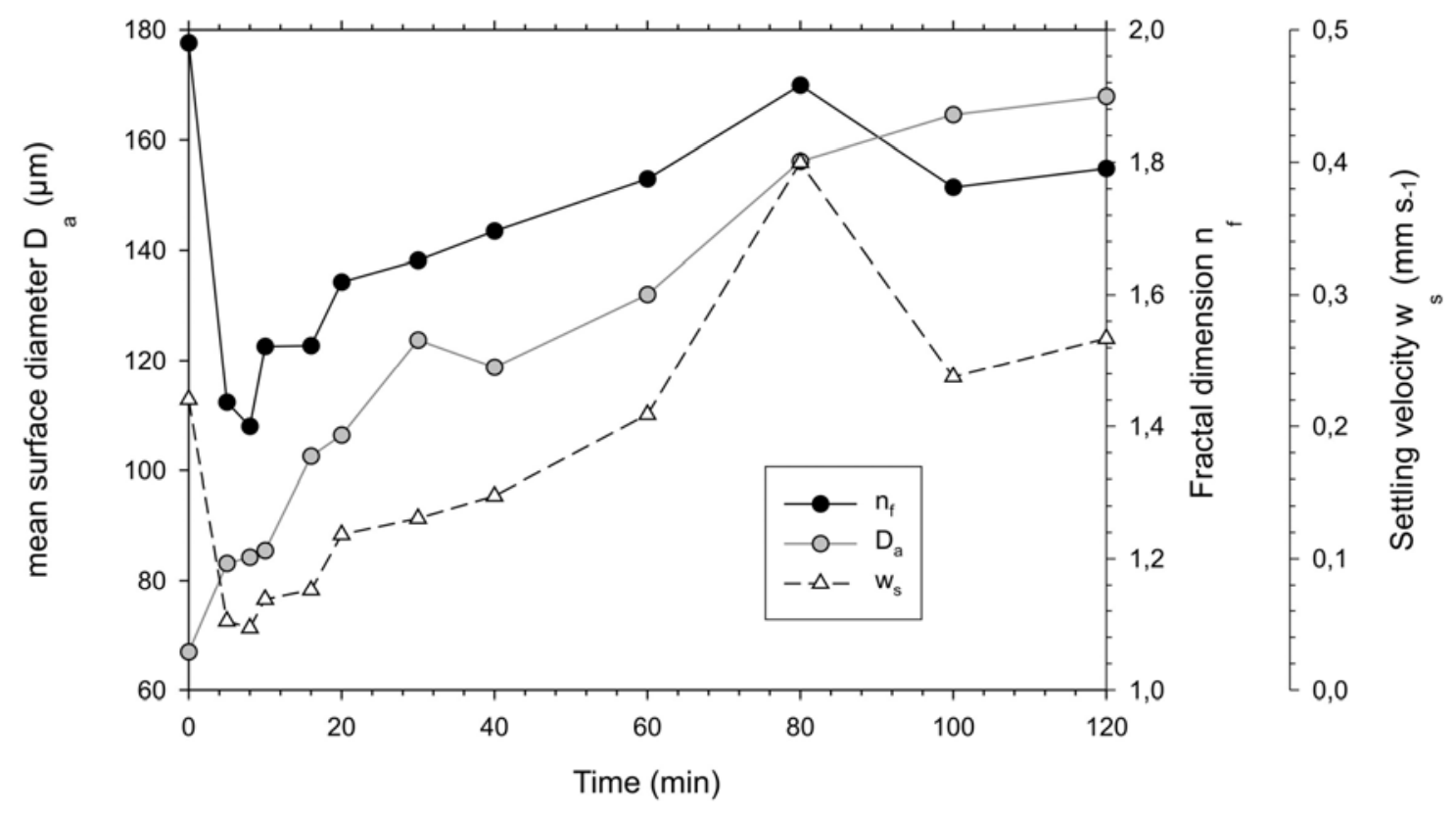


Table I

\begin{tabular}{|c|c|c|c|c|}
\hline & oc typ & 7 th & $\gamma$ & \\
\hline \multirow{4}{*}{ 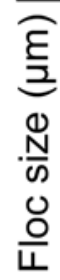 } & $D_{f}$ & 356 & 386 & 398 \\
\hline & $\mathrm{D}_{\mathrm{e}}$ & 320 & 465 & 398 \\
\hline & $\mathrm{D}_{\mathrm{SB}}$ & 409 & 423 & 419 \\
\hline & $\mathrm{D}_{\mathrm{a}}$ & 222 & 366 & 325 \\
\hline
\end{tabular}

